\title{
Tracing tetraether lipids from source to sink in the Rhône River system (NW Mediterranean)
}

\author{
Jung-Hyun Kim ${ }^{1,2 * t}$, Wolfgang Ludwig ${ }^{3}$, Roselyne Buscail ${ }^{3}$, Denise Dorhout ${ }^{1,2}$ and \\ Jaap S. Sinninghe Damsté ${ }^{1,2}$ \\ ${ }^{1}$ Department of Marine Organic Biogeochemistry, NIOZ Royal Netherlands Institute for Sea Research, Den Burg, \\ Netherlands, ${ }^{2}$ Faculty of Geosciences, Utrecht University, Utrecht, Netherlands, ${ }^{3}$ CEFREM-UMR Centre National de la \\ Recherche Scientifique 5110, University of Perpignan, Perpignan, France
}

OPEN ACCESS

Edited by:

Moritz Felix Lehmann University of Basel, Switzerland

Reviewed by:

Carme Huguet,

Universitat Autonoma de Barcelona, Spain

Arnaud Huguet,

CNRS/Université Pierre et

Marie Curie, France

*Correspondence: Jung-Hyun Kim,

Den Burg, Netherlands jhkim123@hanyang.ac.kr

${ }^{\dagger}$ Present Address: Jung-Hyun Kim

Department of Marine Science and Convergence Technology, Hanyang University ERICA Campus, 55 Hanyangdaehak-ro, Sangnok-gu, Ansan-si, Gyeonggi-do 426-791, South Korea

Specialty section: This article was submitted to Biogeoscience, a section of the journal Frontiers in Earth Science

Received: 03 February 2015 Accepted: 13 May 2015 Published: 03 June 2015

Citation:

Kim J-H, Ludwig W, Buscail $R_{\text {, }}$ Dorhout $D$ and Sinninghe Damsté JS (2015) Tracing tetraether lipids from

source to sink in the Rhône River system (NW Mediterranean).

Front. Earth Sci. 3:22 doi: 10.3389/feart.2015.00022
In this study, we investigated soils and river suspended particulate matter (SPM) collected in the Rhône and its tributary basins as well as marine surface sediments taken in the Rhône prodelta (Gulf of Lions, NW Mediterranean). Thereby, we traced the signal of branched glycerol dialkyl glycerol tetraethers (brGDGTs) from the source to sink via the Rhône River and its tributaries and identified sources of brGDGTs in rivers and marine sediments. Soil $\mathrm{pH}$ rather than the mean annual air temperature (MAAT) explains most of the observed variances of the brGDGT distribution in our soil dataset. The observed changes in the distribution of brGDGTs in the river SPM indicate that brGDGTs brought by the river to the sea are primarily derived from the lower Rhône and its tributary soils, even though in situ production in the river itself cannot be excluded. In marine surface sediments, it appears that the input of riverine brGDGTs is the primary source of brGDGTs in the Rhône prodelta, although the brGDGT composition may be further modified by the in situ production in the marine environment. More work is required to assess fully whether brGDGTs can be used to reconstruct the terrestrial paleoenvironmental changes using marine sediment cores taken in the Rhône prodelta close to the river mouth.

Keywords: glycerol dialkyl glycerol tetraethers, crenarchaeol, Rhône River, Gulf of Lions, MBT’/CBT, BIT

\section{Introduction}

Branched glycerol dialkyl glycerol tetraethers (brGDGTs) (see Schouten et al., 2013 for the review) are membrane-spanning lipids, most likely derived from anaerobic (Weijers et al., 2006a) and heterotrophic (Pancost and Sinninghe Damsté, 2003; Oppermann et al., 2010; Weijers et al., 2010) bacteria that occur ubiquitously in peat (e.g., Weijers et al., 2006a) and soil (e.g., Weijers et al., 2007a) as well as in lacustrine/marine sediments and water column (e.g., Blaga et al., 2009; Peterse et al., 2009a; Tierney and Russell, 2009; Pearson et al., 2011; Loomis et al., 2014; Weijers et al., 2014). The brGDGTs contain four to six methyl groups and up to two cyclopentane moieties formed by internal cyclization (Sinninghe Damsté et al., 2000; Weijers et al., 2006a, see Figure 1 for chemical structures). Four of these methyl groups are present in mid-chain positions of the two $\mathrm{C}_{28}$ linear chains of the tetraether structure, whilst the others are present at the C- 5 and C- $5^{\prime}$ positions. Some acidobacterial species may produce brGDGTs (Weijers et al., 2009a), which was confirmed by the recent identification of the brGDGT Ia in two cultured acidobacterial strains from subdivision 1 (Sinninghe Damsté et al., 2011, 2014). However, biological sources of other brGDGTs remain to be identified. 


\section{BrGDGTs}

la

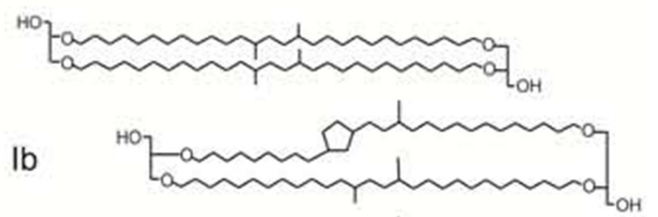

Ic

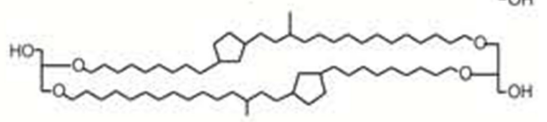

Ila

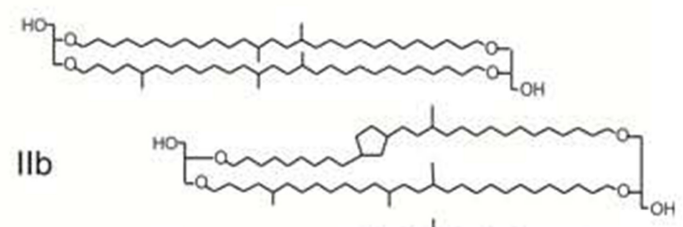

Ic

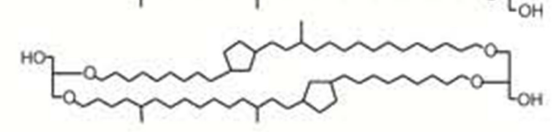

IIla

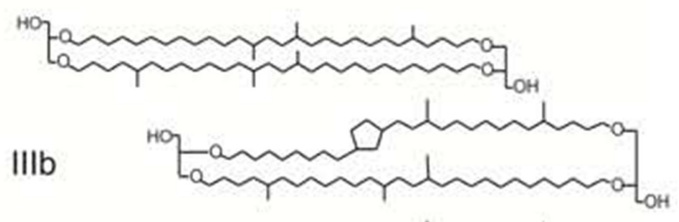

IIIC

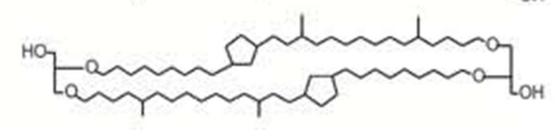

\section{Crenarchaeol}

IV

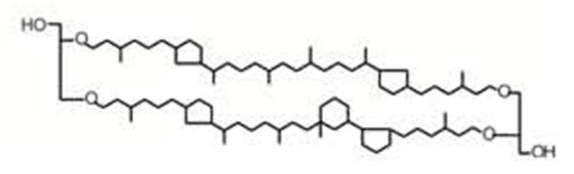

FIGURE 1 | Chemical structure of brGDGTs (la-IIlc) and crenarchaeol (IV).

The methylation index of branched tetraethers (MBT) and the cyclization index of branched tetraethers (CBT) were defined to express the observed variations in the distributions of a set of nine brGDGTs in soil in a quantitative way (Weijers et al., 2007a). The MBT/CBT proxy was then introduced as a paleotemperature proxy for terrestrial environments based on the fact that the CBT correlated with soil $\mathrm{pH}$ and the MBT/CBT with mean annual air temperature (MAAT). Based on an extended soil dataset, the MBT was subsequently adjusted to the MBT, by excluding two minor compounds (brGDGT IIIb and IIIc) in soil (Peterse et al., 2012). This resulted in new global soil calibrations for the reconstruction of soil $\mathrm{pH}$ based on the CBT and for the reconstruction of MAAT based on the MBT'/CBT. For provenance studies of brGDGTs, the degree of cyclization (DC), a ratio that gives an indication of the average number of cyclopentane moieties, over the CBT has been applied because the DC does not use a logarithmic function (Sinninghe Damsté et al., 2009).
Initially, it was thought that brGDGTs are mainly produced in soils, washed into small streams and rivers by soil erosion, and further transported to the ocean where they are deposited in sediments (Hopmans et al., 2004). Hence, by investigating marine sediments deposited close to a river outflow, it would be possible to reconstruct a continuous, long-term continental climate changes using the MBT/CBT proxy. An initial study of Congo deep-sea fan 0-25 ka sedimentary record (Weijers et al., 2007b) showed the potential of the MBT/CBT proxy for providing an integrated MAAT signal of the whole river drainage basin. However, a subsequent study in the Amazon deep-sea fan sediments showed that an increased input of brGDGTs from a particular area of the drainage basin might obscure the representativeness of the entire river basin (Bendle et al., 2010). In addition, in situ production in rivers (e.g., Yang et al., 2013; Zell et al., 2013a,b, 2014a; De Jonge et al., 2014), in lakes (e.g., Tierney and Russell, 2009; Zell et al., 2013a; Buckles et al., 2014), and in marine/estuarine environments (e.g., Peterse et al., 2009a; Zhu et al., 2011; Strong et al., 2012; Zell et al., 2014b) may alter the original brGDGT signal of soils carried by the particles transported by rivers. Hence, the interpretation of the MBT/CBT (hereafter the term of the MBT'/CBT will be used) in marine environments is much more complex than initially anticipated. It is therefore of utmost importance to further investigate how varying environmental conditions in different river systems would affect the application of the MBT'/CBT proxy to reconstruct past MAAT changes using marine sediment cores.

A structurally related isoprenoid GDGT, crenarchaeol (Figure 1), is a membrane-spanning lipid predominantly produced by marine planktonic Group I Crenarchaeota (Sinninghe Damsté et al., 2002), which is now reclassified as the novel phylum Thaumarchaeota (Brochier-Armanet et al., 2008; Spang et al., 2010). Crenarchaeol in combination with three major brGDGTs (Ia, IIa, and IIIa) were used to define the branched and isoprenoid tetraether (BIT) index, as a tool, initially for estimating the relative amounts of riverborne terrestrial organic carbon (OC) in marine sediments (Hopmans et al., 2004) and later more specifically as a proxy for river borne soil OC input (e.g., Huguet et al., 2007; Walsh et al., 2008). The BIT index has also shown potential as a proxy for paleohydrology changes (e.g., Ménot et al., 2006; Verschuren et al., 2009; Weijers et al., 2009b). The BIT index varies between 0 and 1 , representing the marine and terrestrial end members, respectively. However, BIT values in soils are typically lower than the hypothetical end-member value of 1 as crenarchaeol also occurs in soils (e.g., Leininger et al., 2006; Weijers et al., 2006b) albeit in relatively small concentrations. The BIT index is also influenced by the amount of crenarchaeol produced in rivers (e.g., Herfort et al., 2006; Kim et al., 2012; Zell et al., 2013a,b), in lakes (e.g., Powers et al., 2004; Blaga et al., 2009; Zell et al., 2013a), and in marine/estuarine environments (e.g., Fietz et al., 2011; Smith et al., 2012; Zell et al., 2014a,b). Besides, as mentioned above, brGDGTs are not only produced in soils but also in lakes and rivers (e.g., Zell et al., 2013a). This suggests that the BIT index does not indicate OC coming from soils, 
but rather a more general continental OC input. It has also been suggested that the quantification of brGDGT fluxes or concentrations is a better indicator for the recalcitrant OC fraction transported from the continent to the ocean (e.g., Fietz et al., 2011). Further investigation is also needed for the BIT index to better understand how it can be used as a helpful tool to trace the transport of continental $\mathrm{OC}$ and to guide if and where the MBT'/CBT proxy might be applied in marine environments.

We previously performed several GDGT-related studies in the river-dominated continental margin of the Gulf of Lions (NW Mediterranean) and in its adjacent Têt and Rhône basins (Kim et al., 2006, 2007, 2009, 2010, 2014). However, all previous studies were focused on the BIT index, and the applicability of the MBT'/CBT proxy in this area has not been assessed yet. In the present study, we have extended our previous studies to the MBT'/CBT proxy, by analyzing soils and river SPM collected in Rhône and its tributary basins as well as marine surface sediments collected in the Rhône prodelta (Gulf of Lions, NW Mediterranean). To this end, we traced the signal of brGDGTs from source to sink via rivers, identified the sources of brGDGTs in rivers and marine sediments, and assessed the applicability of the GDGT-based proxies in the Rhône prodelta. The brGDGTs are present as intact polar lipids (IPLs) in living cells, which are relatively quickly transformed after cell death into "fossil" core lipids (CLs) (e.g., Harvey et al., 1986). Hence, the concentration and distribution of brGDGTs of both CL and IPL fractions were investigated for river SPM in order to distinguish more recently produced (IPL-derived) GDGTs from older (CL) GDGTs. However, for soils and marine surface sediments only CL fractions were investigated since these samples were not constantly kept frozen prior to GDGT analysis.

\section{Study Area}

The Rhône River (Figure 2) originates in the Swiss Alps, emerging from the Rhône Glacier (Fette et al., 2007). The Rhône River has a total length of $812 \mathrm{~km}$ and a total drainage basin of $98 \times 10^{3} \mathrm{~km}^{2}$ (Pont et al., 2002). The Rhône River is characterized by low winter discharge due to snow detention and high spring and summer discharge caused by the melting of snow and glaciers. The Rhône River discharges on average $\sim 1700 \mathrm{~m}^{3} \mathrm{~s}^{-1}$ of freshwater into the Gulf of Lions, NW Mediterranean (Thill et al., 2001). Hence, the Rhône River is the largest river in terms of its freshwater discharge into the Mediterranean since the damming of the Nile at Aswan (Ludwig et al., 2003). The solid discharge varies between 2 and $20 \times 10^{6}$ tons $\mathrm{yr}^{-1}$ (e.g., Pont et al., 2002; Eyrolle et al., 2012), accounting for $\sim 80 \%$ of the riverine inputs to the Gulf of Lions (Durrieu de Madron et al., 2000). The upper Rhône River basin between Lake Geneva and the headwaters in the Valais region of Switzerland has a MAAT of $4.3^{\circ} \mathrm{C}$ and receives lots of precipitation with a mean annual precipitation (MAP) of ca $1600 \mathrm{~mm}$ (Olivier et al., 2009). The lower Rhône River basin between Lake Geneva and the river mouth has a MAAT of $9.2^{\circ} \mathrm{C}$ and MAP of ca. $1000 \mathrm{~mm}$ (Olivier et al., 2009). However, the southern part of the lower Rhône River basin has a Mediterranean climate with hot and dry summers and a MAP of $\sim 600 \mathrm{~mm}$.

The Rhône River has a number of important tributaries such as the Saône, Ain, Isère, and Durance rivers (Olivier et al., 2009). The Saône River originates at an altitude of $392 \mathrm{~m}$ near Vioménil and joins the Rhône River in Lyon. Its length is $473 \mathrm{~km}$ with a total drainage basin of $29 \times 10^{3} \mathrm{~km}^{2}$ and an average discharge of $410 \mathrm{~m}^{3} \mathrm{~s}^{-1}$. The Saône River basin has a MAAT of $9.6^{\circ} \mathrm{C}$ and MAP of $952 \mathrm{~mm}$. Its largest tributary is the Doubs River with a $453 \mathrm{~km}$ long, a total drainage basin of $7.5 \times 10^{3} \mathrm{~km}^{2}$, and
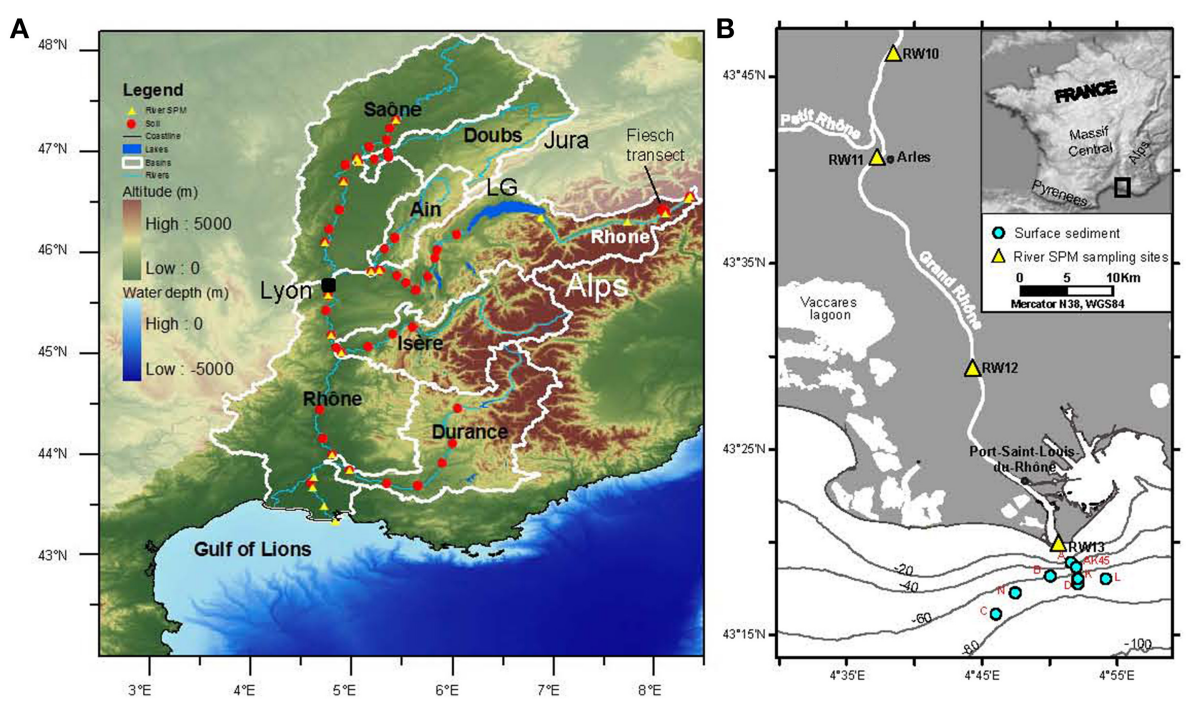

FIGURE 2 | Map showing (A) soil (filled red dots) and SPM (filled yellow triangles) sampling sites in the Rhône basin and its tributary basins (white lines) and (B) multicore positions of the marine surface sediments (filled light blue dots) from the Rhône prodelta in the Gulf of Lions. The sampling locations of SPM (filled yellow triangles) collected near to the Rhône River mouth are also shown in (B). LG in (A) indicates Lake Geneva. 
an average discharge of $180 \mathrm{~m}^{3} \mathrm{~s}^{-1}$. The source of the Doubs River is at an altitude of $937 \mathrm{~m}$ near Mouthe in the western Jura mountains. The Ain River originates at an elevation of $700 \mathrm{~m}$ near La Favière in the southern Jura mountains and flows into the Rhône River about $40 \mathrm{~km}$ above Lyon. Its length is $190 \mathrm{~km}$, and its total drainage basin is $3.6 \times 10^{3} \mathrm{~km}^{2}$ with an average discharge of $130 \mathrm{~m}^{3} \mathrm{~s}^{-1}$. The Ain River basin has a MAAT of $9.2^{\circ} \mathrm{C}$ and MAP of $1010 \mathrm{~mm}$. The Isère River is a $286 \mathrm{~km}$ long, a total drainage basin of $12 \times 10^{3} \mathrm{~km}^{2}$, and an average discharge of $360 \mathrm{~m}^{3} \mathrm{~s}^{-1}$. It rises at an altitude of $2400 \mathrm{~m}$ near Col de l'Iseran in the Alps and flows into the Rhône River above Valence. The Isère River basin has a MAAT of $6.5^{\circ} \mathrm{C}$ and MAP of $1300 \mathrm{~mm}$. The Durance River originates at an altitude of $2300 \mathrm{~m}$ near Montgenèvre in the south-western Alps and flows into the Rhône River near Avignon. Its length is $324 \mathrm{~km}$, and its total drainage basin is $14 \times 10^{3} \mathrm{~km}^{2}$ with an average discharge of $188 \mathrm{~m}^{3} \mathrm{~s}^{-1}$. The Durance River basin has a MAAT of $8.8^{\circ} \mathrm{C}$ and MAP of $1079 \mathrm{~mm}$.

In the marine coastal area, close to the Rhône River mouth, most of the sediment delivered by the river is primarily entrapped in the subaqueous prodelta $\left(30 \mathrm{~km}^{2}\right)$, between 0 and $20 \mathrm{~m}$ water depth (Maillet et al., 2006; Ulses et al., 2008). In fact, most of the material delivered by the Rhône River accumulates in the prograding prodelta which extends from the shoreline to $60 \mathrm{~m}$ water depth (Maillet et al., 2006; Wright and Friedrichs, 2006). The sedimentation rates in the prodelta are 20 to $50 \mathrm{~cm} \mathrm{yr}^{-1}$ at shallow stations $(\sim 20 \mathrm{~m})$ near the river mouth (Charmasson et al., 1998; Radakovitch et al., 1999), $\sim 1 \mathrm{~cm} \mathrm{yr}^{-1}$ at $60 \mathrm{~m}$ water depth where the prodelta ends, and then strongly decreasing seaward, with a mean rate $<0.3 \mathrm{~cm} \mathrm{yr}^{-1}$ on the continental shelf (Zuo et al., 1997; Radakovitch et al., 1999; Miralles et al., 2005).

\section{Material and Methods}

\section{Sample Collection}

Sampling of top soils (upper $10 \mathrm{~cm}$ ) in the Rhône River basin was performed in September 2009 and July 2012 from the source (Rhône Glacier) area in the Swiss Alps to the river mouth into the Gulf of Lions, NW Mediterranean (Table 1; Figure 2A). The soil sampling sites were generally within a few hundred meters from the river and divided into two parts: upper Rhône River basin (from the Rhône Glacier to Lake Geneva, $n=2$ ) and lower Rhône River basin (after Lake Geneva to the river mouth, $n=17$ ). Top soils were also sampled between $2848 \mathrm{~m}$ and $1188 \mathrm{~m}$ altitude along the Fiesch transect (i.e., from the Fiescher Glacier area to Fiesch, Switzerland, $n=16$ ) and near to the Rhône Glacier $(n=2)$ in the upper Rhône River basin. In addition, top soils were collected in September 2009 in its tributary basins (Table 1; Figure 2A): Saône $(n=13)$, Doubs $(n=5)$, Ain $(n=5)$, Isère $(n=4)$, and Durance $(n=6)$. All samples were immediately deep-frozen in a portable freezer in the field and were stored frozen at $-40^{\circ} \mathrm{C}$ until they were further freeze dried and homogenized prior to analysis.

Rhône River SPM was collected close to the water surface from the source (Rhône Glacier) area to the river mouth in September 2009, May 2010 and July 2012 (Table 1; Figures 2A,B): upper Rhône River $(n=5)$ and lower Rhône River $(n=8)$. In addition, River SPM was collected in September 2009 in the various tributaries (Table 1; Figure 2A), i.e., Saône $(n=4)$, Doubs $(n=1)$, Ain $(n=1)$, Isère $(n=1)$, and Durance $(n=1)$. For the determination of the concentration of SPM and its elemental composition, water was collected manually with a bucket. A small portion of the collected water (0.5-0.7 1) was filtered onto ashed $\left(450^{\circ} \mathrm{C}\right.$, overnight $)$ and pre-weighed glass fiber filters (Whatman GF/F, $0.7 \mu \mathrm{m}, 47 \mathrm{~mm}$ diam.). For GDGT analysis, 5-23 L water were filtered onto pre-ashed glass fiber filters (Whatman GF/F, $0.7 \mu \mathrm{m}, 142 \mathrm{~mm}$ diam.). All samples were immediately deep-frozen in a portable freezer in the field and were kept frozen at $-20^{\circ} \mathrm{C}$ until they were freeze dried before analysis.

The multi-corer surface sediments $(0-0.5 \mathrm{~cm} ; n=8)$ were collected from the Rhône prodelta during the CHACCRA Bent 2 cruise (R/V Le Suroît) in December 2008 (Table 1; Figure 2B). All samples were immediately deep-frozen at $-20^{\circ} \mathrm{C}$ on board and they were freeze dried and homogenized prior to analysis.

\section{Determination of Environmental Parameters}

To determine the $\mathrm{pH}$ of the soils, a mixture of soil and distilled water (1:3.5, w:w) was prepared. This mixture was stirred vigorously and left to settle down for $20 \mathrm{~min}$. For the $\mathrm{pH}$ measurements, a $\mathrm{pH}$ analyzer (Wissenschaftlich-Technische Werkstätten $\mathrm{pH}$ 315i/SET and probe $\mathrm{pH}$-Electrode SenTix 41, $\mathrm{pH}$ range $0-14, \mathrm{~T}$ range $0-80^{\circ} \mathrm{C}$, stored in $3 \mathrm{~mol} \mathrm{~L}^{-1} \mathrm{KCl}$ ) was calibrated with CertiPUR buffer solutions with $\mathrm{pH} 4.01$, 7.00 , and 10.00. The $\mathrm{pH}$ and the temperature of the river water were measured in situ with the Wissenschaftlich-Technische Werkstätten $\mathrm{pH}$ analyzer at the time of SPM sampling, after calibration of the electrode.

The MAAT and MAP data for each soil sampling site were extracted for the time period of $\sim 1950-2000$ from the WorldClim dataset with a grid point resolution of $1 \mathrm{~km} \mathrm{x}$ $1 \mathrm{~km}$ (http://www.worldclim.org/). More information about the climatic data sets can be found in Hijmans et al. (2005).

\section{Bulk Geochemical Analysis}

For the OC analysis, soils and river SPM filters were decarbonated with $2 \mathrm{~mol} \mathrm{~L}^{-1} \mathrm{HCl}$ (overnight at $50^{\circ} \mathrm{C}$ ) and with $\mathrm{HCl}$ vapor as described by Lorrain et al. (2003), respectively. They were analyzed with a Thermo Flash EA 1112 Elemental Analyzer interfaced with a Thermo Finnigan Delta ${ }^{\text {Plus }}$ mass spectrometer. The OC content of the marine surface sediments was obtained using an elemental analyzer (LECO CN 2000), after acidification with $2 \mathrm{~mol} \mathrm{~L}^{-1} \mathrm{HCl}$ (overnight at $50^{\circ} \mathrm{C}$ ) to remove carbonate. The OC content is expressed as the weight percentage of dry sediment (wt.\%). The analyses were determined at least in duplicate, and the analytical error was on average better than 0.2 wt.\%.

\section{Lipid Extraction and Purification}

For the analysis of CL GDGTs, soils and marine sediments were extracted with an accelerated solvent extractor (DIONEX ASE 200) using DCM:MeOH (9:1, v:v) at $100^{\circ} \mathrm{C}$ and 1500 psi. The ASE extracts were collected in vials. Solvents were removed using Caliper Turbovab ${ }^{\circledR} \mathrm{LV}$, and the extracts were taken up in DCM, 
TABLE 1 | Environmental and bulk geochemical data of soils and river SPM collected in the Rhône River and its tributary basins and marine surface sediments collected in the Rhône prodelta (Gulf of Lions, NW Mediterranean).

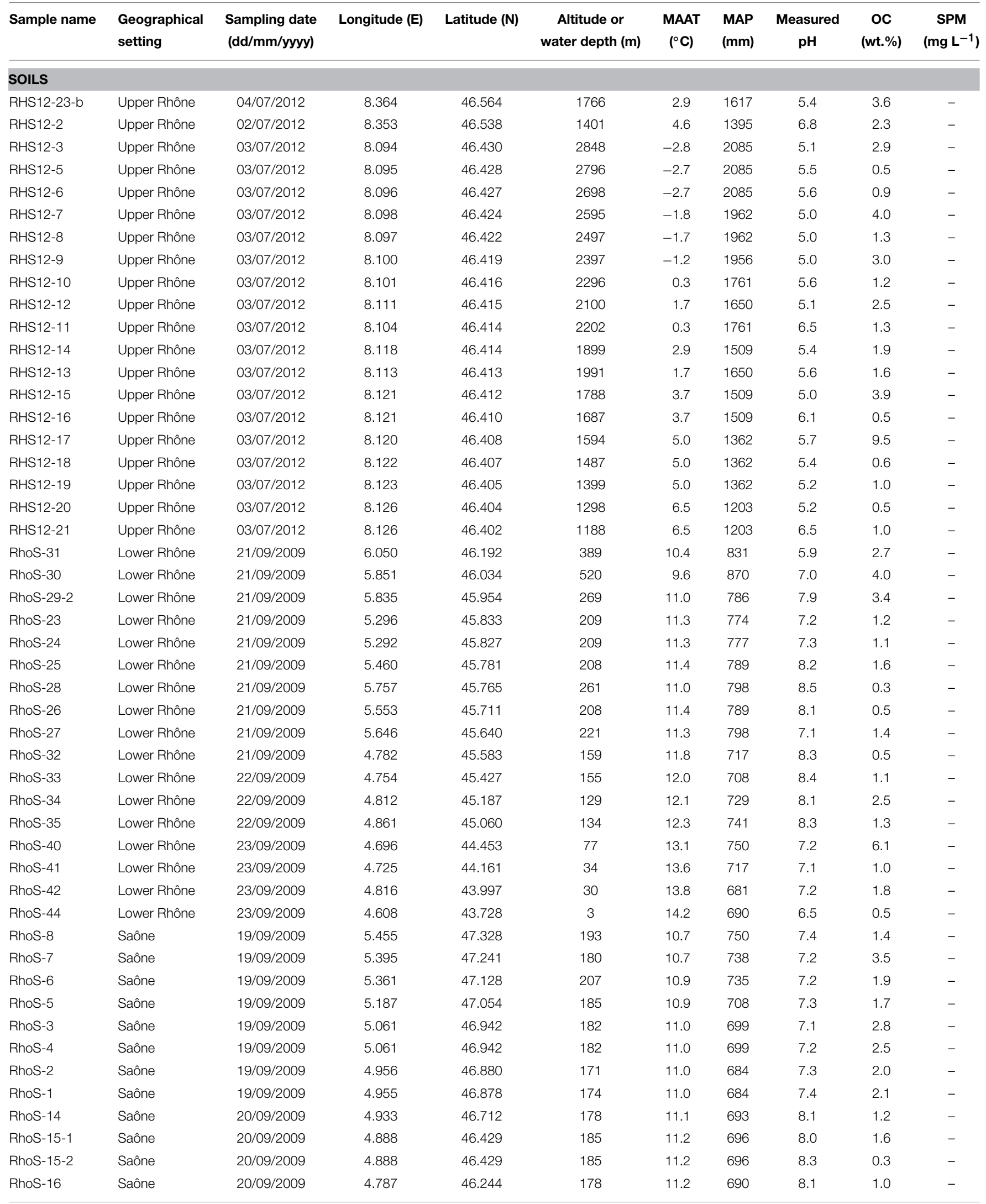


TABLE 1 | Continued

\begin{tabular}{|c|c|c|c|c|c|c|c|c|c|c|}
\hline Sample name & $\begin{array}{l}\text { Geographical } \\
\text { setting }\end{array}$ & $\begin{array}{l}\text { Sampling date } \\
\text { (dd/mm/yyyy) }\end{array}$ & Longitude (E) & Latitude (N) & $\begin{array}{c}\text { Altitude or } \\
\text { water depth (m) }\end{array}$ & $\begin{array}{c}\text { MAAT } \\
\left({ }^{\circ} \mathrm{C}\right)\end{array}$ & $\begin{array}{l}\text { MAP } \\
(\mathrm{mm})\end{array}$ & $\begin{array}{c}\text { Measured } \\
\text { pH }\end{array}$ & $\begin{array}{c}\text { OC } \\
\text { (wt. \%) }\end{array}$ & $\begin{array}{c}\text { SPM } \\
\left(\mathrm{mg} \mathrm{L}^{-1}\right)\end{array}$ \\
\hline RhoS-17 & Saône & 20/09/2009 & 4.747 & 46.110 & 173 & 11.3 & 687 & 8.2 & 1.1 & - \\
\hline RhoS-9 & Doubs & 19/09/2009 & 5.377 & 47.003 & 192 & 10.9 & 750 & 7.4 & 1.7 & - \\
\hline RhoS-10 & Doubs & 19/09/2009 & 5.379 & 46.955 & 187 & 10.9 & 747 & 7.2 & 0.2 & - \\
\hline RhoS-11 & Doubs & 19/09/2009 & 5.379 & 46.955 & 187 & 10.9 & 747 & 7.8 & 3.2 & - \\
\hline RhoS-12 & Doubs & 19/09/2009 & 5.244 & 46.932 & 194 & 11.0 & 723 & 7.8 & 2.7 & - \\
\hline RhoS-13 & Doubs & 19/09/2009 & 5.084 & 46.903 & 165 & 11.0 & 702 & 8.2 & 0.6 & - \\
\hline RhoS-18 & Ain & 20/09/2009 & 5.443 & 46.159 & 370 & 10.7 & 825 & 7.8 & 1.4 & - \\
\hline RhoS-20 & Ain & 20/09/2009 & 5.448 & 46.151 & 275 & 10.9 & 795 & 7.3 & 1.4 & - \\
\hline RhoS-21 & Ain & 20/09/2009 & 5.337 & 46.046 & 248 & 11.1 & 765 & 7.3 & 0.7 & - \\
\hline RhoS-22-1 & Ain & 21/09/2009 & 5.212 & 45.818 & 192 & 11.3 & 771 & 7.4 & 2.5 & - \\
\hline RhoS-22-2 & Ain & 21/09/2009 & 5.212 & 45.818 & 192 & 11.3 & 771 & 8.5 & 0.1 & - \\
\hline RhoS-39-1 & Isère & 22/09/2009 & 5.618 & 45.271 & 199 & 11.4 & 789 & 7.0 & 1.4 & - \\
\hline RhoS-38 & Isère & 22/09/2009 & 5.426 & 45.193 & 229 & 11.5 & 804 & 5.2 & 2.7 & - \\
\hline RhoS-37 & Isère & 22/09/2009 & 5.175 & 45.075 & 150 & 11.8 & 786 & 8.0 & 0.5 & - \\
\hline RhoS-36 & Isère & 22/09/2009 & 4.908 & 45.014 & 125 & 12.3 & 750 & 8.7 & 0.4 & - \\
\hline RhoS-50 & Durance & 24/09/2009 & 6.060 & 44.462 & 607 & 10.4 & 747 & 8.3 & 0.8 & - \\
\hline RhoS-49 & Durance & 24/09/2009 & 6.009 & 44.110 & 437 & 11.6 & 696 & 8.4 & 1.3 & - \\
\hline RhoS-48 & Durance & 24/09/2009 & 5.904 & 43.924 & 354 & 12.2 & 678 & 7.4 & 1.6 & - \\
\hline RhoS-45 & Durance & 24/09/2009 & 4.989 & 43.851 & 65 & 13.6 & 630 & 7.3 & 1.4 & - \\
\hline RhoS-46 & Durance & 24/09/2009 & 5.366 & 43.713 & 163 & 13.2 & 609 & 8.3 & 0.5 & - \\
\hline RhoS-47 & Durance & 24/09/2009 & 5.668 & 43.692 & 243 & 12.9 & 639 & 7.6 & 4.4 & - \\
\hline \multicolumn{11}{|l|}{ RIVER SPM } \\
\hline RW1 & Upper Rhône & 04/07/2012 & 8.364 & 46.564 & 1766 & 7.7 & - & 8.5 & 0.3 & 59 \\
\hline RW2 & Upper Rhône & 02/07/2012 & 8.349 & 46.534 & 1381 & 7.4 & - & 8.6 & 0.3 & 2003 \\
\hline RW3 & Upper Rhône & 03/07/2012 & 8.126 & 46.392 & 988 & 11.5 & - & 8.8 & 0.2 & 433 \\
\hline RW4 & Upper Rhône & 04/07/2012 & 7.743 & 46.306 & 623 & 9.4 & - & 8.4 & 0.2 & 140 \\
\hline RW5 & Upper Rhône & 01/07/2012 & 6.888 & 46.349 & 348 & 10.7 & - & 8.4 & 0.2 & 166 \\
\hline RW6 & Lower Rhône & 21/09/2009 & 5.292 & 45.827 & 209 & 17.9 & - & 8.3 & 18.5 & 2 \\
\hline RW7 & Lower Rhône & 21/09/2009 & 4.782 & 45.583 & 159 & 18.5 & - & 8.6 & 19.4 & 7 \\
\hline RW8 & Lower Rhône & 22/09/2009 & 4.812 & 45.187 & 129 & 20.1 & - & 7.8 & 23.5 & 6 \\
\hline RW9 & Lower Rhône & 23/09/2009 & 4.816 & 43.997 & 30 & 22.6 & - & 8.0 & 8.1 & 9 \\
\hline RW10 & Lower Rhône & 18/05/2010 & 4.640 & 43.774 & 3 & 14.8 & - & 7.9 & 1.9 & 25 \\
\hline RW11 & Lower Rhône & 19/05/2010 & 4.622 & 43.679 & 3 & 14.8 & - & 7.9 & 2.2 & 23 \\
\hline RW12 & Lower Rhône & 20/05/2010 & 4.743 & 43.488 & 3 & 14.8 & - & 8.0 & 2.2 & 21 \\
\hline RW13 & Lower Rhône & 20/05/2010 & 4.846 & 43.334 & 0 & 14.8 & - & 8.0 & 2.0 & 12 \\
\hline SW1 & Saône & 19/09/2009 & 5.455 & 47.328 & 193 & 20.0 & - & 7.6 & 11.1 & 6 \\
\hline SW2 & Saône & 19/09/2009 & 5.061 & 46.942 & 182 & 19.5 & - & 8.0 & 7.4 & 11 \\
\hline SW3 & Saône & 20/09/2009 & 4.933 & 46.712 & 178 & 18.7 & - & 8.1 & 8.9 & 3 \\
\hline SW4 & Saône & 20/09/2009 & 4.747 & 46.110 & 173 & 19.5 & - & 8.2 & 10.5 & 8 \\
\hline DW1 & Doubs & 19/09/2009 & 5.084 & 46.903 & 165 & 19.9 & - & 8.2 & 18.2 & 3 \\
\hline AW1 & Ain & 21/09/2009 & 5.212 & 45.818 & 192 & 12.8 & - & 8.5 & 10.9 & 3 \\
\hline IW1 & Isère & 22/09/2009 & 4.908 & 45.014 & 125 & 17.1 & - & 8.0 & 6.5 & 4 \\
\hline Du2 & Durance & 24/09/2009 & 4.989 & 43.851 & 65 & 19.1 & - & 7.6 & 3.3 & 5 \\
\hline \multicolumn{11}{|c|}{ MARINE SURFACE SEDIMENTS } \\
\hline A & Rhône prodelta & 02/12/2008 & 4.852 & 43.310 & 21 & - & - & - & 1.22 & - \\
\hline AK45 & Rhône prodelta & 04/12/2008 & 4.855 & 43.307 & 46 & - & - & - & 4.06 & - \\
\hline$B$ & Rhône prodelta & 02/12/2008 & 4.829 & 43.303 & 54 & - & - & - & 1.96 & - \\
\hline C & Rhône prodelta & 02/12/2008 & 4.776 & 43.274 & 73 & - & - & - & 1.49 & - \\
\hline $\mathrm{D}$ & Rhône prodelta & 02/12/2008 & 4.856 & 43.299 & 74 & - & - & - & 1.16 & - \\
\hline K & Rhône prodelta & 02/12/2008 & 4.856 & 43.300 & 67 & - & - & - & 1.62 & - \\
\hline$L$ & Rhône prodelta & 02/12/2008 & 4.883 & 43.303 & 66 & - & - & - & 1.11 & - \\
\hline $\mathrm{N}$ & Rhône prodelta & 02/12/2008 & 4.795 & 43.293 & 63 & - & - & - & 1.36 & - \\
\hline
\end{tabular}

"-" Indicates no data available. Note that the temperature values of the river SPM sites represent instantaneous water temperatures measured at the time of sampling. 
dried over anhydrous $\mathrm{Na}_{2} \mathrm{SO}_{4}$, and blown down under a stream of $\mathrm{N}_{2}$. For quantification of GDGTs, $0.1 \mu \mathrm{g}$ internal standard $\left(\mathrm{C}_{46}\right.$ GDGT) was added to each total extract before it was separated into three fractions over an activated $\mathrm{Al}_{2} \mathrm{O}_{3}$ column (activated for $2 \mathrm{~h}$ at $\left.150^{\circ} \mathrm{C}\right)$ using hexane:DCM $(9: 1, \mathrm{v}: \mathrm{v})$, hexane:DCM (1:1, $\mathrm{v}: \mathrm{v})$ and DCM:MeOH (1:1, v:v).

In order to analyze both CL and IPL-derived GDGTs, the river SPM filters were freeze-dried and extracted using a modified Bligh and Dyer method (White et al., 1979; Pitcher et al., 2009). The Bligh and Dyer extracts were separated into CL and IPL fractions over a silica gel column (activated for $2 \mathrm{~h}$ at $\left.150^{\circ} \mathrm{C}\right)$ with $n$-hexane:ethyl acetate $(1: 1, \mathrm{v}: \mathrm{v})$ and $\mathrm{MeOH}$ as eluents, respectively. For the GDGT quantification, $0.01 \mu \mathrm{g}$ of $\mathrm{C}_{46}$ GDGT internal standard was added to each fraction. The CL fractions were further separated into two fractions over an activated $\mathrm{Al}_{2} \mathrm{O}_{3}$ column using hexane:DCM (1:1, v:v) and DCM:MeOH (1:1, v:v), respectively. Two third of the IPL fraction was hydrolyzed to obtain IPL-derived CLs as described by Weijers et al. (2011).

\section{GDGT Analysis and Calculation of GDGT-Based Indices}

For soils and marine sediments, the DCM:MeOH fractions were analyzed for CL GDGTs. During the separation of CL and IPL fractions, a small amount of the CL GDGTs were carried over into the IPL fraction (Pitcher et al., 2009). Therefore, for the river SPM samples the CL fractions, the hydrolyzed IPL fractions, and the non-hydrolyzed IPL fractions were analyzed in order to implement a correction for more accurately calculating the amounts of CL and IPL-derived GDGTs as described by Weijers et al. (2011). Note that the two different extraction methods used for quantification of CL GDGTs would provide comparable results (cf. Lengger et al., 2012). All samples were analyzed using high-performance liquid chromatography-atmospheric pressure positive ion chemical ionization-mass spectrometry (HPLCAPCI-MS) with an Agilent 1100 series LC-MSD SL. The GDGTs were separated on an Alltech Prevail Cyano column $(150 \mathrm{~mm} \times$ $2.1 \mathrm{~mm} ; 3 \mu \mathrm{m}$ ) using the method described by Schouten et al. (2007) and modified by Peterse et al. (2012). Quantification was achieved by calculating the area of the corresponding peak in the chromatogram and comparing it with the peak area of the internal standard and correcting for the different response factors. All CL GDGTs, except for CL brGDGT IIIb and IIIc, were well above the detection limit following the suggestion by Schouten et al. (2007). The analytical error was determined by duplicate measurements of $12 \mathrm{CL} \mathrm{GDGT}_{S}$ and 7 IPL-derived brGDGTs fractions. For the concentration of summed brGDGTs (the sum of all the brGDGTs), the analytical error was $11 \%$ for the CL GDGTs and 6\% for the IPL-derived GDGTs. Crenarchaeol concentrations had the analytical error of $17 \%$ for the CL GDGTs and $10 \%$ for the IPL-derived GDGTs. The carryover of CL brGDGTs into the IPL fraction was, on average, $10 \pm 14 \%$ while that of crenarchaeol was $0 \%$.

The BIT index (Hopmans et al., 2004), the MBT' (Peterse et al., 2012), the CBT (Weijers et al., 2007a), and the DC (Sinninghe Damsté et al., 2009) were calculated as follows:

$$
\begin{aligned}
\text { BIT index }= & \frac{[\mathrm{Ia}]+[\mathrm{IIa}]+[\mathrm{IIIa}]}{[\mathrm{Ia}]+[\mathrm{IIa}]+[\mathrm{III}]+[\mathrm{IV}]} \\
\text { MBT }^{\prime}= & \frac{[\mathrm{Ia}]+[\mathrm{Ib}]+[\mathrm{Ic}]}{[\mathrm{Ia}]+[\mathrm{Ib}]+[\mathrm{Ic}]+[\mathrm{IIa}]} \\
& +[\mathrm{IIb}]+[\mathrm{IIc}]+[\mathrm{III}] \\
\mathrm{CBT}= & -\log \left(\frac{[\mathrm{Ib}]+[\mathrm{IIb}]}{[\mathrm{Ia}]+[\mathrm{IIa}]}\right) \\
\mathrm{DC}= & \frac{[\mathrm{Ib}]+[\mathrm{IIb}]}{[\mathrm{Ia}]+[\mathrm{Ib}]+[\mathrm{IIa}]+[\mathrm{IIb}]}
\end{aligned}
$$

The numerals refer to the GDGTs depicted in Figure 1. The analytical error in the determination of the BIT index was 0.01 (CL) and 0.03 (IPL-derived) and the MBT' 0.01 (CL) and 0.06 (IPL-derived), and the DC 0.01 (CL) and 0.05 (IPLderived). For the calculation of $\mathrm{pH}$ and MAAT from the brGDGT distribution of soils, river SPM, and marine sediments, the global soil calibrations by Peterse et al. (2012) were used as follows:

$$
\begin{aligned}
\mathrm{pH} & =7.90-1.97 \times \mathrm{CBT}\left(R^{2}=0.70\right) \\
\mathrm{MAAT} & =0.81-5.67 \times \mathrm{CBT}+31.0 \times \mathrm{MBT}^{\prime}\left(R^{2}=0.59\right)
\end{aligned}
$$

\section{Statistical Analysis}

We performed a Principal Component Analysis (PCA) on the fractional abundance data of brGDGTs as well as a Hierarchical Clustering on Principal Components (HCPC) on the PCA results to better visualize and highlight the similarities between samples. Fractional abundances of each brGDGT component were obtained by normalizing each peak area to the summed area of all brGDGTs considered. We also performed the nonparametric Mann-Whitney $U$ test, which does not meet the normality assumption of the One-Way analysis variance (ANOVA), to evaluate the differences in mean values between two different groups in a similar way to Zell et al. (2013b). Groups that showed a significant difference $(p<0.05)$ were assigned different letters. The statistical tests were performed using the R-3.0.3 package.

\section{Results}

\section{Soils}

Soils from the upper Rhône River basin (i.e., between the Rhône Glacier and the Lake Geneva) were more acidic, with $\mathrm{pH}$ values of $5.5 \pm 0.5$ (average \pm standard deviation $[1 \sigma]$ ), whereas soils from the lower Rhône River basin were more alkaline, with $\mathrm{pH}$ values of $7.5 \pm 0.7$ (Table 1). Soils from the five tributary basins were also alkaline with $\mathrm{pH}$ values of $7.6 \pm 0.6$. The TOC content of the Rhône soils varied between 0.5 and 9.5 wt.\%, with similar average values of the upper $(2.2 \pm 2.0 \mathrm{wt} . \%)$ and lower $(1.8 \pm 1.5$ wt.\%) Rhône soils (Table 1). The TOC content of soils from the five tributary basins ranged from 0.1 to $4.4 \mathrm{wt} . \%$, with an average value $(1.6 \pm 1.0$ wt.\%) similar to the Rhône soils. In general, soil characteristics in each tributary basin were similar in term of soil $\mathrm{pH}$ and TOC content, comparable to those of the soils from the lower Rhône River basin. 
CL brGDGTs were found in all Rhône soils. However, CL brGDGT IIIb and IIIc were often below the detection limit or detected in small amounts (Figure 3), which is in good agreement with a previous study of globally distributed soils (Peterse et al., 2012). For the upper Rhône soils, the fractional abundance of brGDGT IIa $(0.45 \pm 0.04)$ and Ia $(0.36 \pm 0.08)$ were the highest (Figure 3A). BrGDGT IIIb and IIIc were below the detection limit. For the lower Rhône soils, brGDGT IIa $(0.37 \pm 0.04)$ was also the most abundant compound. However, brGDGT IIb $(0.24 \pm 0.05)$ was more abundant than brGDGT Ia $(0.15 \pm 0.03)$ (Figure 3A). The average of the CL brGDGT concentration $\left(19 \pm 12 \mu \mathrm{g} \mathrm{gOC}^{-1}\right.$ ) (normalized to OC to account for differences in grain size) was an order of magnitude higher than that of crenarchaeol $\left(0.4 \pm 0.4 \mu \mathrm{g} \mathrm{gOC}^{-1}\right)$ in the upper Rhône River basin (Figure 4A). As a consequence, the relative amount of CL brGDGTs to CL crenarchaeol, which is defined as the BIT index, was high in the upper Rhône River basin $(0.97 \pm 0.04$, Figure 5A). The concentrations of CL brGDGTs $\left(11 \pm 10 \mu \mathrm{g} \mathrm{gOC}^{-1}\right)$ were lower, albeit in a similar range, and the $\mathrm{CL}$ crenarchaeol concentrations $\left(3 \pm 2 \mu \mathrm{g} \mathrm{gOC}^{-1}\right)$ were higher in the lower Rhône soils, resulting in a reduced CL BIT index $(0.62 \pm 0.2)$ (Figure 5B). The average CL MBT' was $0.39 \pm 0.07$ and $0.29 \pm 0.04$ while the average CL DC was $0.05 \pm 0.05$ and $0.41 \pm 0.07$ for the upper and lower Rhône soils, respectively (Figures 5A,B).

In the soils of the tributary basins, the distribution of $\mathrm{CL}$ brGDGTs in the tributary soils strongly resembled that of the lower Rhône soils (Figure 3A). The concentrations of CL brGDGTs $\left(15 \pm 15 \mu \mathrm{g} \mathrm{goC}^{-1}\right)$ and CL crenarchaeol $(5 \pm 4 \mu \mathrm{g}$
gOC $^{-1}$ ) were more similar to those in the lower Rhône River basin than in the upper Rhône River basin (Figures 4C-G; see also Table 2). Hence, CL BIT values in the tributary basins were much lower $(0.61 \pm 0.19$, Figures $5 \mathbf{C}-\mathbf{G})$ than those in the upper Rhône River basin but similar to those in the lower Rhône River basin. The average CL MBT' was $0.31 \pm 0.07$ while the average CL DC was $0.43 \pm 0.11$ (Figures 5C-G).

\section{River SPM}

The $\mathrm{pH}$ of the river water was relatively constant at $8.1 \pm 0.3$ with similar values in the Rhône River and all its tributaries (Table 1). The SPM samples from the upper Rhône River were collected during days with high precipitation. Hence, the concentration of SPM was much greater in the upper Rhône River (560 \pm $\left.730 \mathrm{mg} \mathrm{L}^{-1}\right)$ than in the lower Rhône River $\left(13 \pm 8 \mathrm{mg} \mathrm{L}^{-1}\right)$, where the SPM samples were collected during a dry period. The concentration of SPM in its tributaries ranged from 3 to $11 \mathrm{mg}$ $\mathrm{L}^{-1}\left(5 \pm 3 \mathrm{mg} \mathrm{L}^{-1}\right)$, comparable to that of the lower Rhône River. The average OC content of SPM (Table 1) was much lower in the upper Rhône River $(0.3 \pm 0.1$ wt.\%) than in the lower Rhône River (10 \pm 9 wt.\%). The tributaries had comparable SPM OC concentration to that of the lower Rhône River, with the average value of $10 \pm 4$ wt.\%.

In the upper Rhône SPM, the most abundant CL brGDGTs was brGDGT IIa $(0.44 \pm 0.02)$ while brGDGT Ia $(0.34 \pm$ 0.14 ) was the most abundant IPL-derived brGDGT (Figure 3B). BrGDGT IIa was most abundant in both CL $(0.40 \pm 0.04)$ and IPL-derived $(0.35 \pm 0.08)$ fractions of the lower Rhône SPM (Figure 3B). BrGDGT IIb did not show much variation

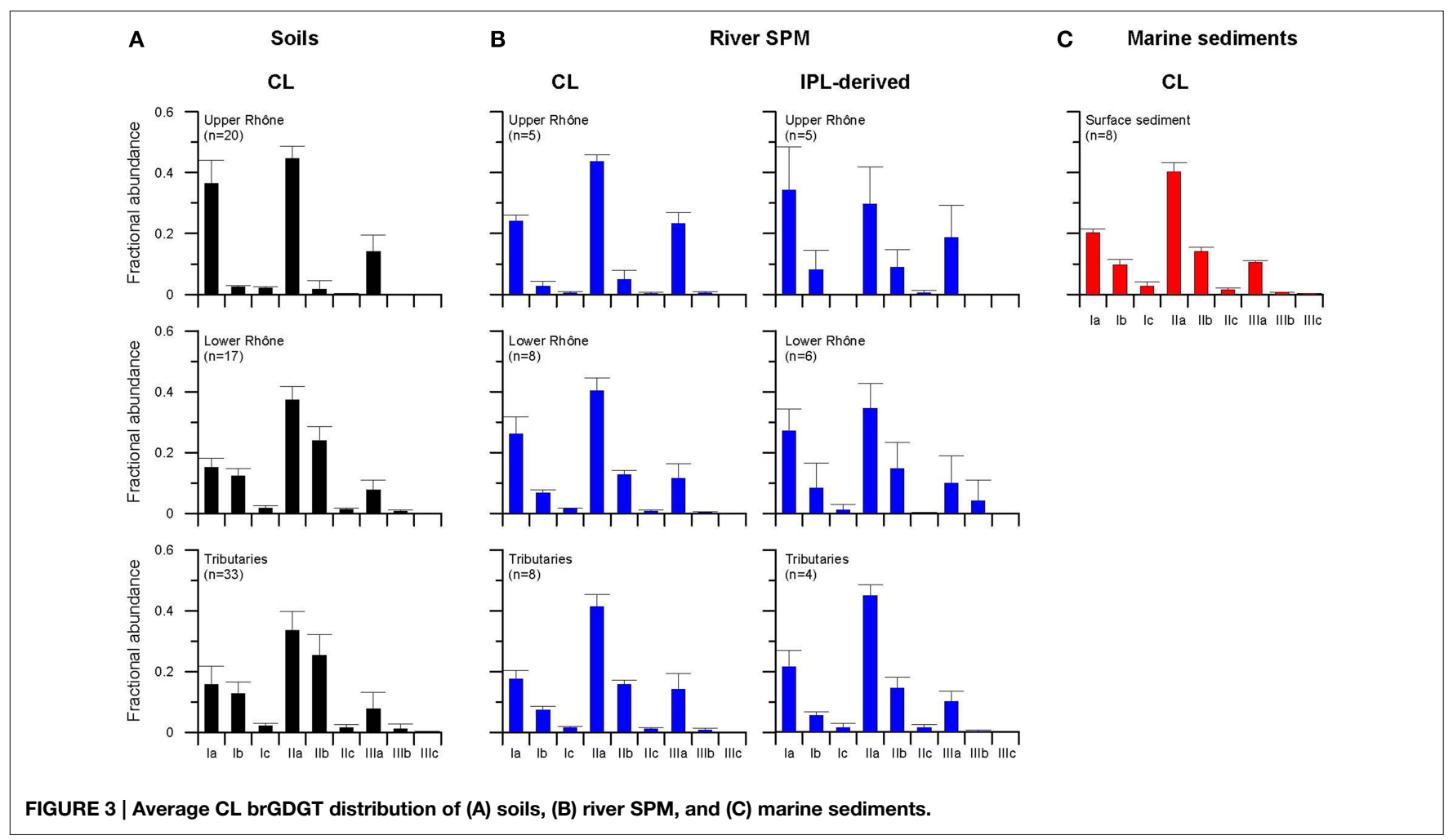


A

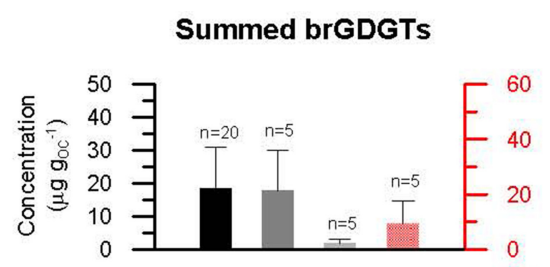

B

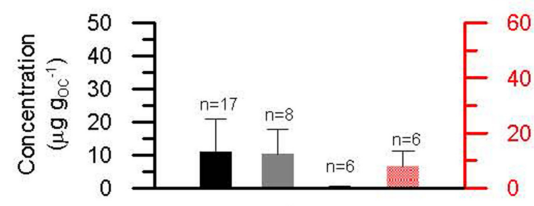

C

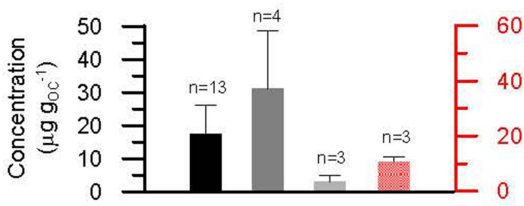

D

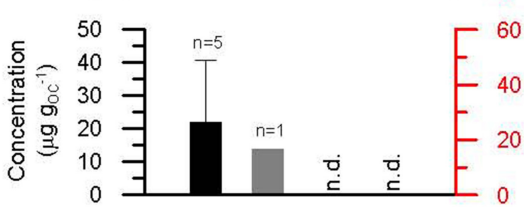

E

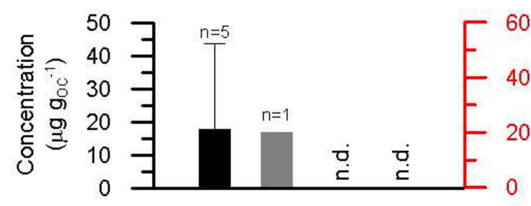

$\mathbf{F}$

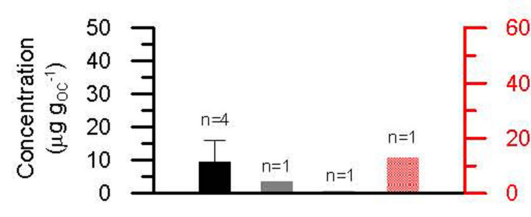

G

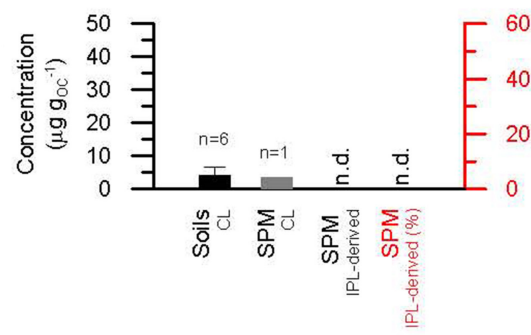

FIGURE 4 | Histograms of the concentration $\left(\mu \mathrm{g} \mathrm{goc}^{-1}\right)$ of summed $C L$ and IPL-derived brGDGTs (the sum of all the brGDGTs) and crenarchaeol normalized to $\mathrm{OC}$ and the IPL-derived fractions (\%) from soils and SPM collected in the

in fractional abundance as for the soil data set but cyclic brGDGTs were relatively more abundant in the lower Rhône SPM. The average CL brGDGT concentration was $18 \pm 12 \mu \mathrm{g}$ $\mathrm{g}_{\mathrm{OC}}{ }^{-1}$ and the percentage of IPL-derived brGDGTs was $9 \pm 8$ (Figure 4A; see also Table 3). The CL brGDGT concentration and the percentage of IPL-derived brGDGTs in the lower Rhône SPM were comparable to those of the upper Rhône SPM, with the average values of $10 \pm 8 \mu \mathrm{g} \mathrm{gOC}^{-1}$ and $8 \pm 6 \%$ (Figure 4B). The CL crenarchaeol concentration was on average $2 \pm 1$ and 1
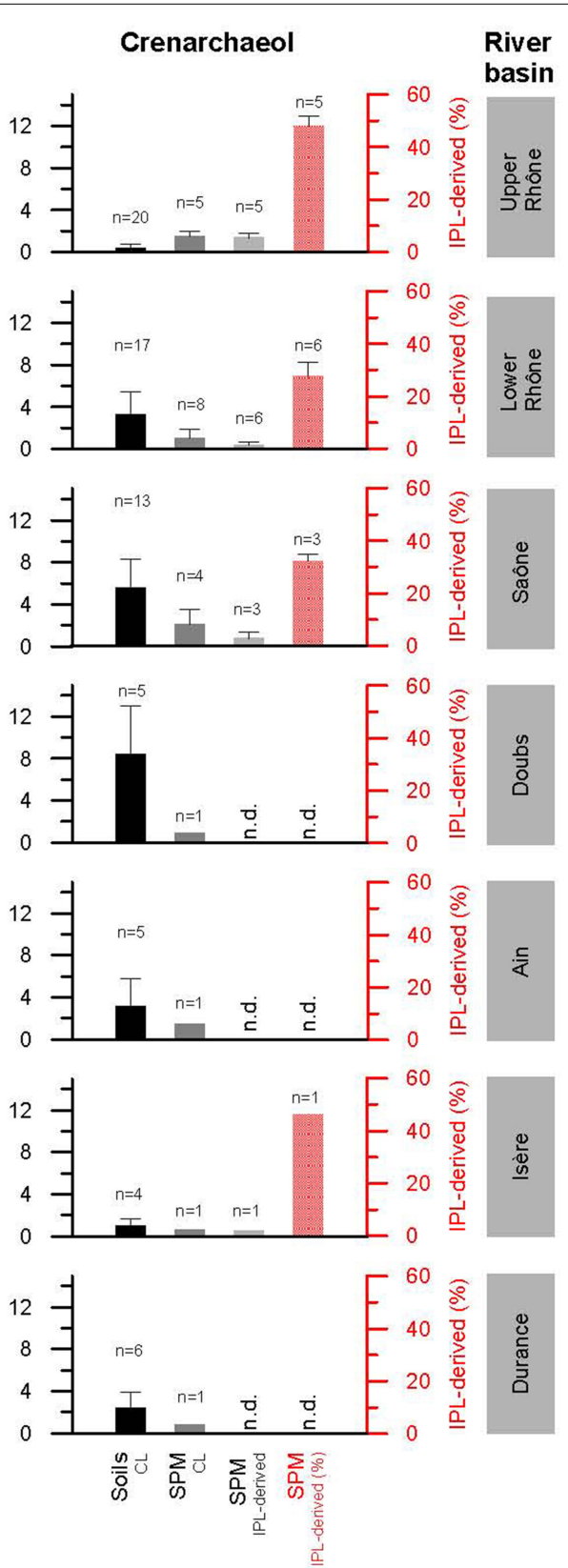

upper (A) and lower (B) Rhône River basin as well as in its tributary basins of Saône (C), Doubs (D), Ain (E), Isère (F), and Durance (G). Note that "n.d." indicates no data available. Letters indicate statistically significant groups of data $(p<0.05)$.

$\pm 1 \mu \mathrm{g} \mathrm{gOC}^{-1}$ in the upper and lower Rhône River, respectively (Figures 4A,B). The percentage of IPL-derived crenarchaeol was much higher than that of IPL-derived brGDGTs amounting $48 \pm$ 4 and $28 \pm 5 \%$ in the upper and lower Rhône River, respectively. The resulting BIT index in the upper Rhône River was $0.90 \pm$ 0.03 in CL fractions and $0.54 \pm 0.13$ in IPL-derived fractions (Figure 5A). The lower Rhône SPM had BIT values for CL $(0.89 \pm 0.02)$ and IPL-derived $(0.53 \pm 0.19)$ fractions similar to those of the upper Rhône SPM (Figure 5B). The average CL 


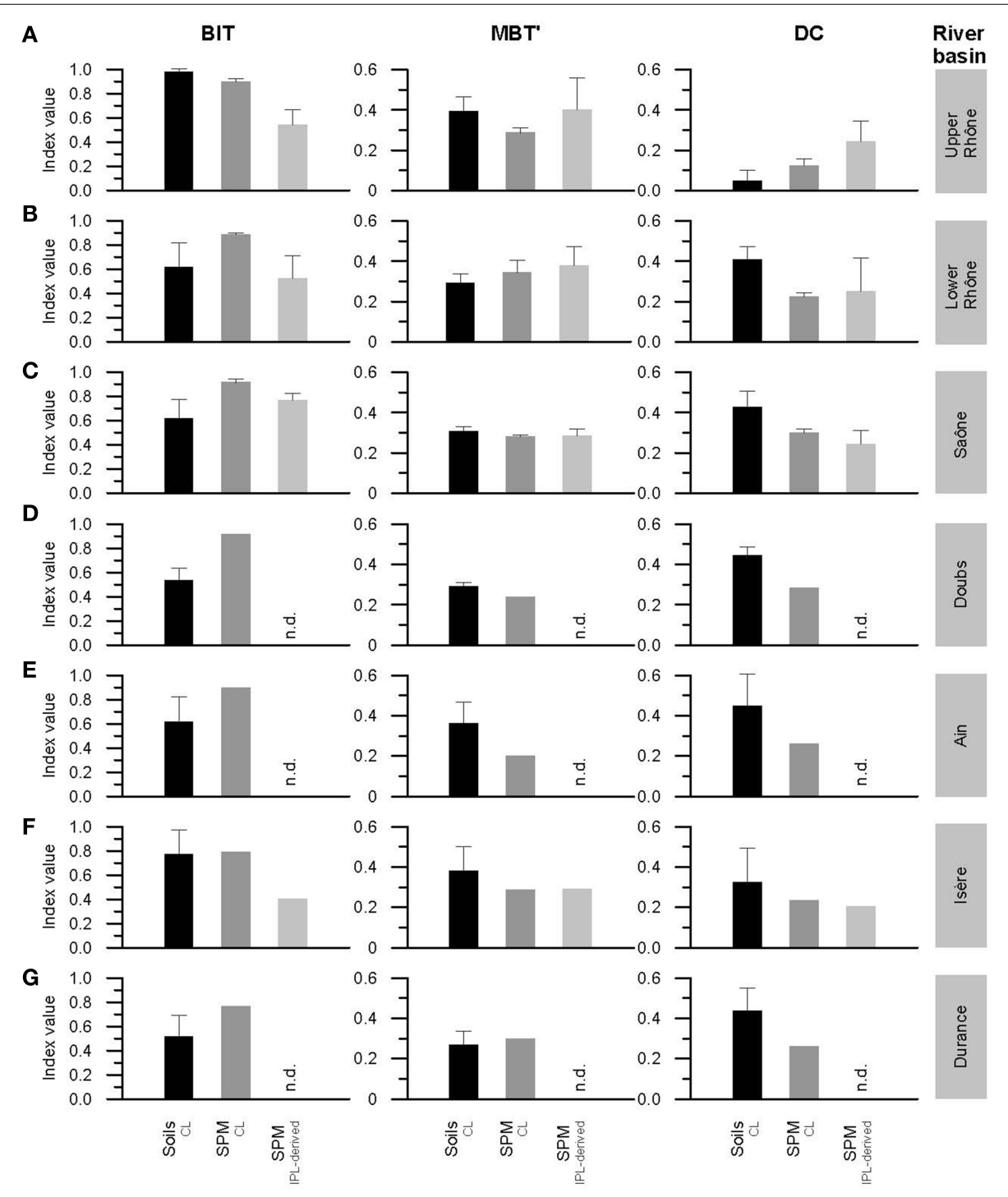

FIGURE 5 | Histograms of the BIT index, the MBT', and the DC of CL and IPL-derived fractions from soils and river SPM collected in the upper (A) and lower (B) Rhône River basin as well as in its tributary basins of Saône (C), Doubs (D), Ain (E), Isère (F), and Durance (G). Note that "n.d." indicates no data available. Letters indicate statistically significant groups of data $(p<0.05)$.
MBT' and CL DC values were $0.29 \pm 0.02$ and $0.12 \pm 0.04$ in the upper Rhône SPM, respectively, while the average MBT' and DC values in IPL-derived fractions were $0.40 \pm 0.16$ and $0.24 \pm 0.10$, respectively (Figure 5A). In the lower Rhône SPM, the average CL MBT' $(0.35 \pm 0.06)$ and CL DC $(0.23 \pm 0.02)$ were, in general, higher than in the upper Rhône SPM but the average MBT' $(0.38 \pm 0.09)$ and DC $(0.25 \pm 0.16)$ in IPL-derived fractions were comparable (Figure 5B).

In the SPM of the tributaries, the concentration of $\mathrm{CL}$ brGDGTs varied between 3 and $56 \mu \mathrm{g} \mathrm{goc}^{-1}$, with the average value of $20 \pm 17 \mu \mathrm{g} \mathrm{goc}^{-1}$ (Figures 4C-G; see also Table 3). The IPL-derived brGDGTs was 11 and 13\% in Saône and Isère SPM, respectively. IPL-derived brGDGTs were under the detection limit in SPM from Doubs, Ain, and Durance. The distribution of CL brGDGTs in tributary SPM strongly resembled that of
IPL-derived brGDGTs as well as that of CL and IPL-derived brGDGTs in the lower Rhône River, with the highest fractional abundance of brGDGT IIa (Figure 3B). The CL crenarchaeol concentration ranged from 1 to $4 \mu \mathrm{g} \mathrm{gOC}^{-1}$ (Figures $4 \mathrm{C}-\mathrm{G}$ ). The IPL-derived crenarchaeol was 32 and $46 \%$ in Saône and Isère SPM, respectively. The BIT index, MBT', and DC values in CL fractions were on average $0.88 \pm 0.06,0.27 \pm 0.03$, and $0.28 \pm 0.03$, respectively, while in IPL-derived fractions they were $0.68 \pm 0.17,0.29 \pm 0.03$, and $0.23 \pm 0.06$, respectively (Figures 5C-G).

\section{Marine Surface Sediments}

The marine surface sediments in the Rhône prodelta had an average TOC content between 1 and 4 wt.\% (Table 1). The most abundant CL brGDGTs were IIa $(0.40 \pm 0.03)$ and Ia $(0.20 \pm$ 


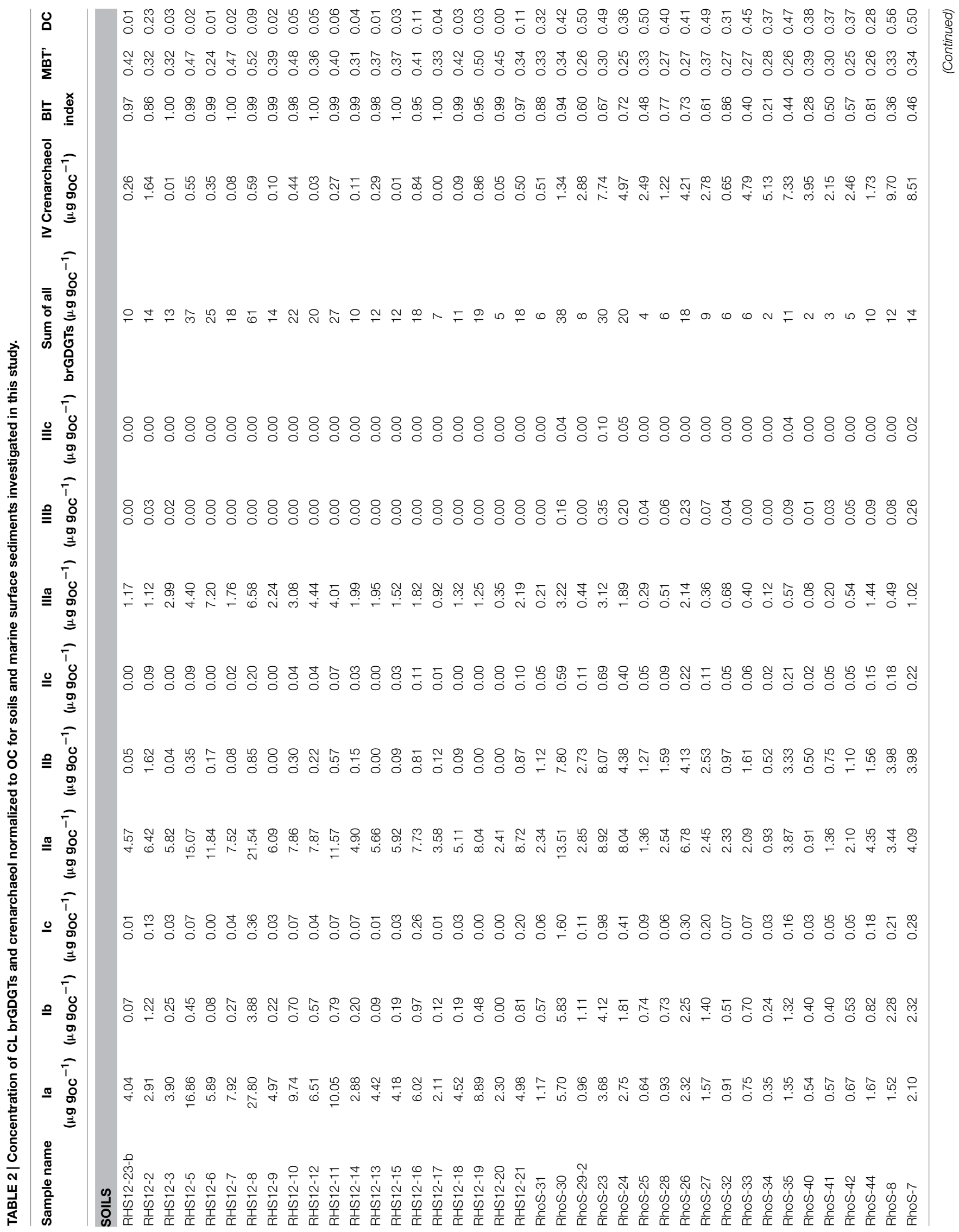




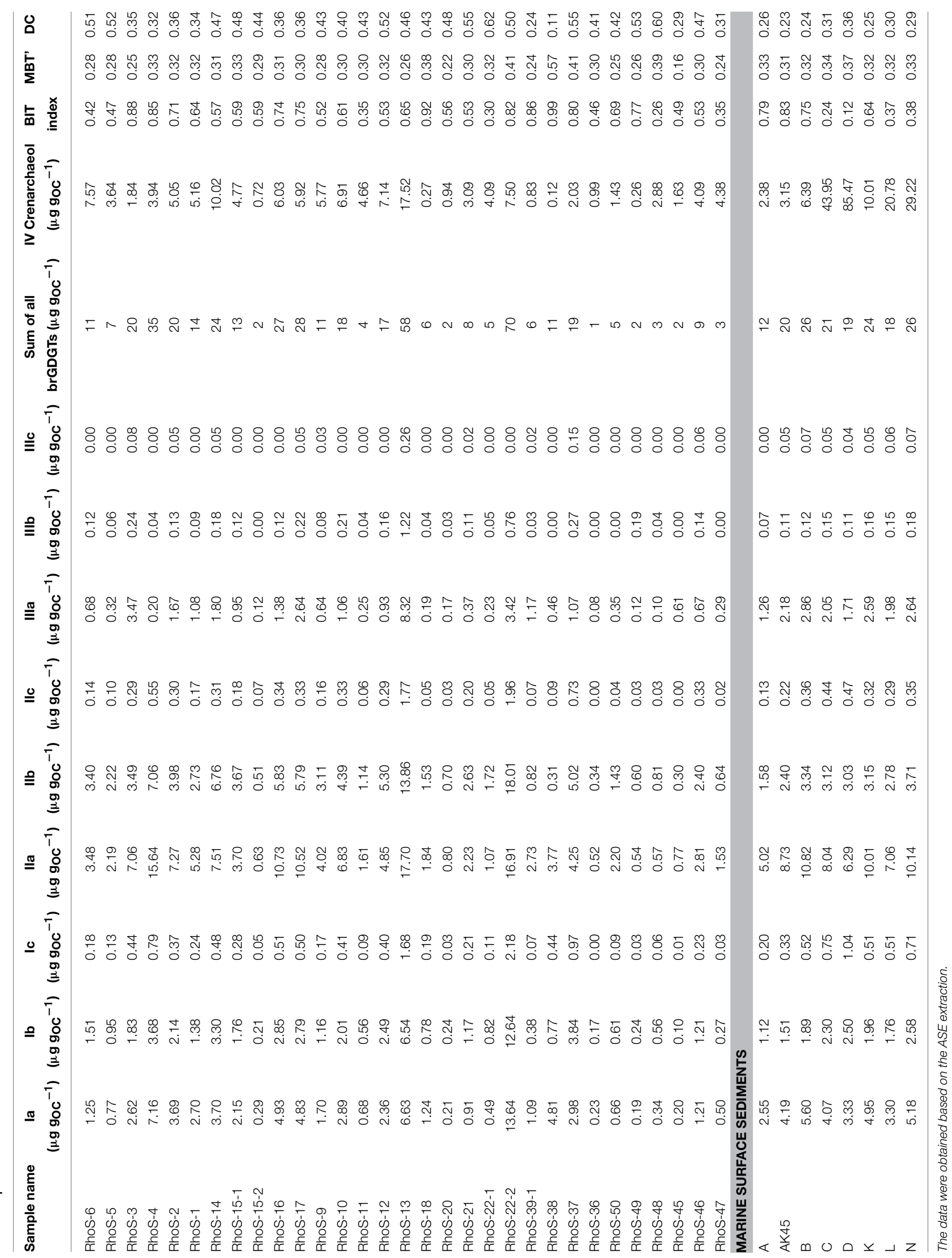




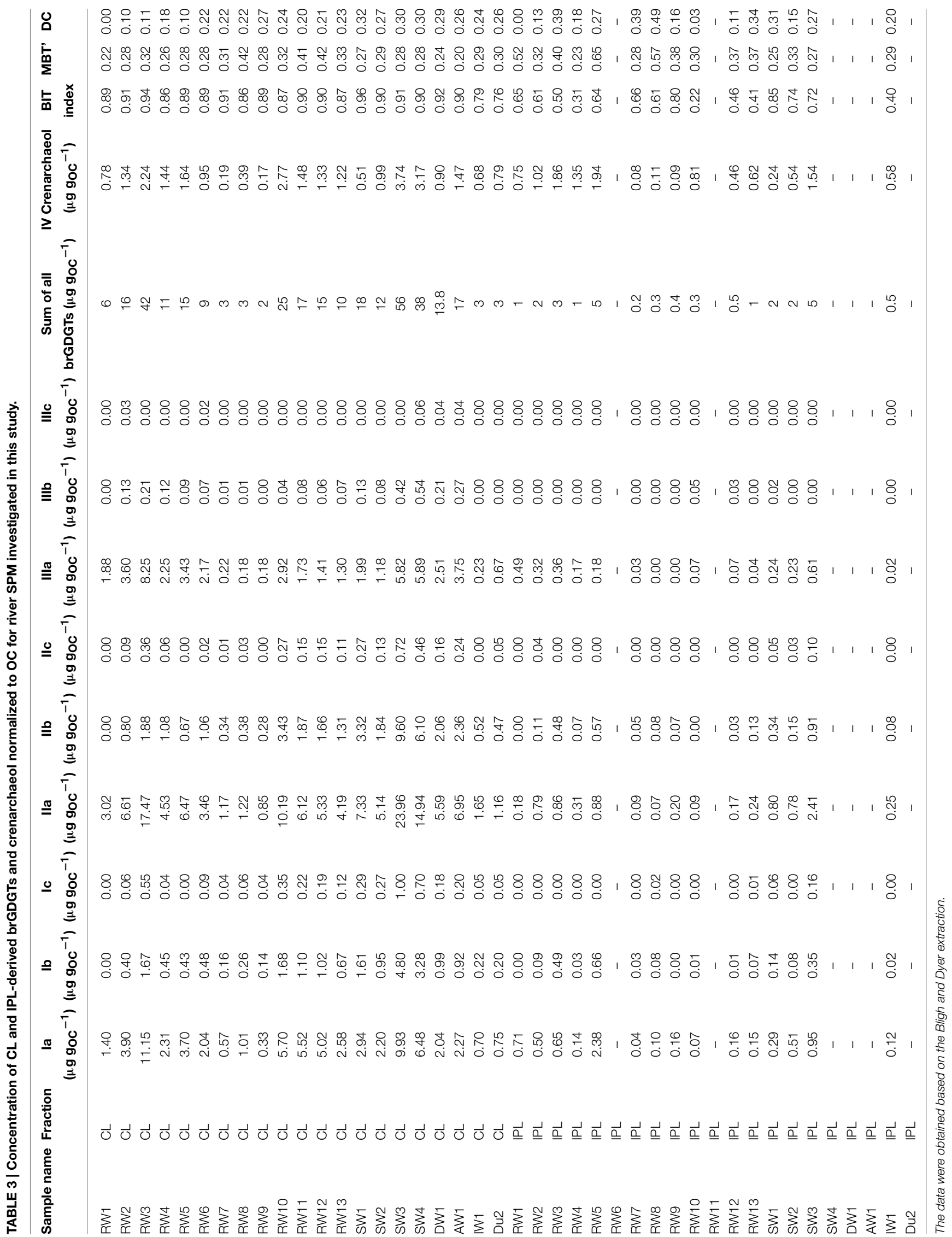


0.01) (Figure 3C). The CL brGDGT concentrations ranged from 12 to $26 \mu \mathrm{g} \mathrm{gOC}^{-1}$, with a generally slightly increasing trend from the Grand Rhône River mouth (Figure 6A; see also Table 2). The crenarchaeol concentrations mainly varied between 2 and $40 \mu \mathrm{g} \mathrm{gOC}^{-1}$, except for one outlier at $85 \mu \mathrm{g} \mathrm{gOC}^{-1}$ (Figure 6B). The CL BIT index varied between 0.12 and 0.83 , showing a trend toward lower values with increasing distance from the river mouth (Figure 6C). The average CL MBT' was $0.33 \pm 0.02$, and the CL DC was $0.28 \pm 0.04$. Both CL MBT' and CL DC did not show a distinctive trend with increasing distance from the river mouth (Figures 6D,E).

\section{Statistical Analyses}

PCA was performed on the fractional abundances of brGDGTs to provide a general view of the variability of the distribution of brGDGTs. GDGT IIIb and IIIc were excluded from this
A$$
\text { 일 }
$$

B

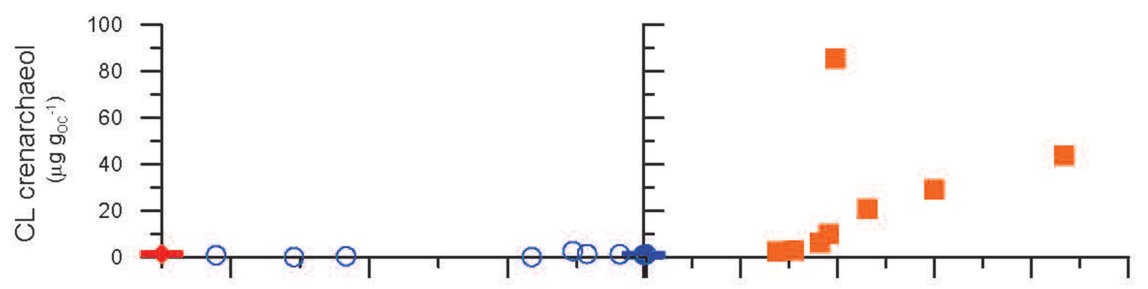

C

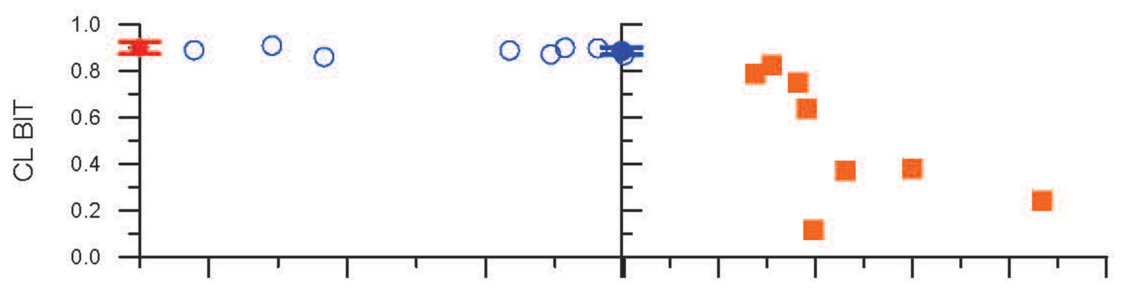

D

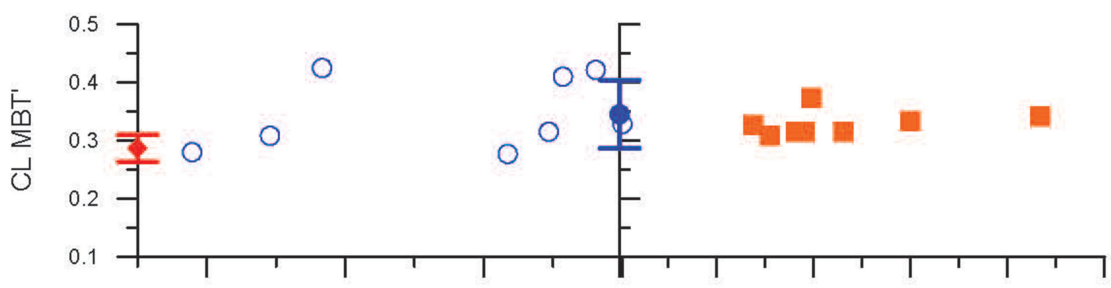

E

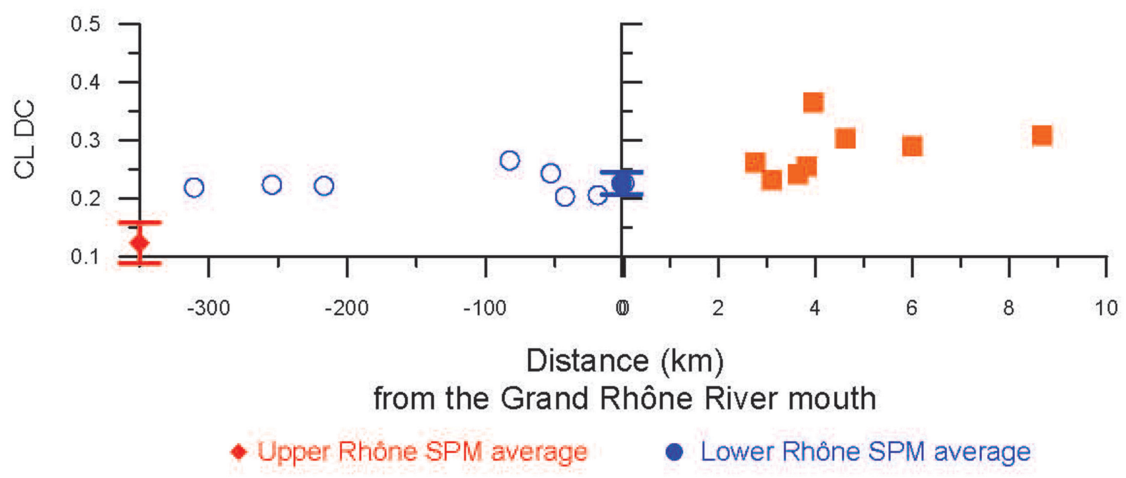

FIGURE 6 | Scatter plots of the distances from the Grand Rhône River mouth and (A) summed brGDGTs $\left(\mu \mathrm{g} \mathrm{goc}^{-1}\right)$, (B) crenarchaeol $(\mu \mathrm{g}$ $\mathrm{goc}^{-1}$ ), (C) the BIT index, (D) the MBT', and (E) the DC of CL fractions from the lower Rhône SPM (open blue circles) as well as the marine surface sediments (filled orange squares). The average values of the upper Rhône SPM (filled red diamonds) and the lower Rhône SPM (filled blue circles) are also shown with the $1 \sigma$ standard deviation. Letters indicate statistically significant groups of data $(p<0.05)$. 
analysis since they were mostly below the detection limit. For the CL brGDGTs of the soils, the river SPM, and the marine surface sediments, the first two principal components explained a cumulative $79.5 \%$ of the variance (Figure 7 ). On the first principal component (PC1, explaining $67.3 \%$ of the variance) the loading of GDGT Ia, IIa, and IIIa was opposite to that of all other brGDGTs, which all contain cyclopentane moieties. On the second principal component (PC2, explaining $12.2 \%$ of the variance), GDGT Ia was negatively loaded while GDGT IIIa positively loaded. We also performed a hierarchical clustering of principal components (HCPC) on the PCA results to cluster samples with similar brGDGT distributions. The samples investigated were grouped into three distinct clusters, i.e., Cluster 1, 2, and 3 (Figure 7).

\section{Discussion}

\section{Abundance and Distribution of GDGTs in Soils}

Our results did not reveal a distinct relationship between the concentrations of CL brGDGTs in soils and soil pH (Figure 8A). However, the concentrations of CL crenarchaeol in soils were in general higher with increasing soil $\mathrm{pH}(>7$, Figure 8B), resulting in lower BIT values (Figure 8C). This is in good agreement with previous studies which showed that soil $\mathrm{pH}$ was positively related to CL crenarchaeol concentrations and thus negatively associated with BIT values (e.g., Weijers et al., 2006b; Kim et al., 2010; Yang et al., 2011; Zell et al., 2014a). It has been previously suggested that soil $\mathrm{pH}$ might more strongly influence the occurrence of the source organisms producing crenarchaeol than those producing brGDGTs (Kim et al., 2010). Recently, lower BIT values in soils have also been attributed to a dryer

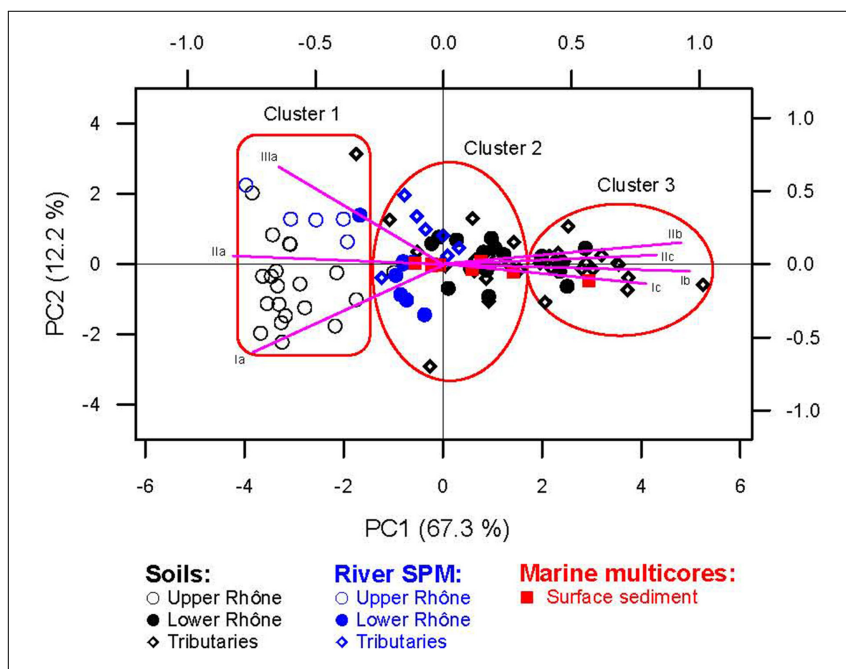

FIGURE 7 | Results of the Principal Component Analysis (PCA) for CL brGDGTs of the soils, the river SPM, and the marine surface

sediments. The first two PCs explain $79.5 \%$ of the variation in the data. Symbols and purple lines represent scores and response variables (brGDGTs), respectively. Note that GDGT IIIb and IIlc were not included in the analysis due to the detection limit. Three clusters resulting from a Hierarchical Clustering on Principal Components (HCPC) were highlighted as red circles. climate, i.e., lower MAP ( $<600 \mathrm{~mm}$ ) (Xie et al., 2012; Dirghangi et al., 2013). Due to deeper oxygen penetration in dryer soils (Cleveland et al., 2010) a dryer climate might be more favorable for nitrifying (i.e., requiring oxygen) crenarchaeol-producing Thaumarchaeota than for the presumably facultative anaerobic brGDGT-producing bacteria (Xie et al., 2012). The soil sampling sites in the upper Rhône River basin have an average MAP of ca. $1600 \mathrm{~mm}$ and an average soil $\mathrm{pH}$ of 6 (Table 1). On the other hand, the soil sampling sites in the lower Rhône River basin and its tributary basins experience a less humid, Mediterranean climate with an average MAP of ca. $750 \mathrm{~mm}$ and soils are more alkaline with an average soil $\mathrm{pH}$ of 8 (Table 1). Hence, it appears that the more alkaline and better-oxygenated soil conditions in the lower Rhône River and its tributary basins are associated with higher CL crenarchaeol concentrations and thus lower CL BIT values.

Although the impact of soil $\mathrm{pH}$ on the concentration of CL brGDGTs seems to be less evident than on the CL crenarchaeol concentration, it clearly affected the distribution of brGDGTs, i.e., DC values of CL brGDGTs were substantially higher with increasing soil $\mathrm{pH}$ values (Figure $\mathbf{8 E}$ ). Hence, this is in good agreement with previous studies that showed the influence of soil $\mathrm{pH}$ on the distribution of CL and IPL-derived brGDGTs in soils (Weijers et al., 2007a; Peterse et al., 2010). In our dataset, the soils of the lower Rhône River and its tributary basins showed a significantly higher CL DC (i.e., $>0.2$ ) compared to the soils from the upper Rhône River basin (Figures 9E, 10). Hence, it appears that more alkaline and better-oxygenated soil conditions in the lower Rhône River and its tributary basins are associated with a higher CL DC and thus a higher CBT-derived pH (data not shown). It is also notable that the CL DC values stabilize at ca. 0.5 when the soil $\mathrm{pH}$ is $>7$ (Figure 8E). This apparent insensitivity of DC (or the CBT) to $\mathrm{pH}$ in alkaline soils has also been observed in long-term soil $\mathrm{pH}$ manipulation plots in Scotland (Peterse et al., 2010) and in Chinese soils (e.g., Xie et al., 2012). It has been postulated that the distribution of brGDGTs is mainly controlled by soil moisture associated with the MAP in alkaline soils in arid/semi-arid regions (Yang et al., 2014). However, in our study area, the CL DC (or CL CBT) was not correlated with the MAP for the sub-dataset with $\mathrm{pH}>7\left(R^{2}=\right.$ 0.006 , data not shown). Therefore, further studies are required to better constrain potential environmental factors such as nutrient condition in soil influencing the distribution of brGDGTs in alkaline soils.

The distribution of the CL brGDGTs in the upper Rhône soils differed substantially from that of the lower Rhône and tributary soils (Figure 3A), which is reflected in the provenance plot of CL MBT' vs. CL DC (Figure 10). The PCA and the subsequent HCPC confirmed this observation, showing that the upper Rhône soils grouped in Cluster 1, whereas Clusters 2 and 3 contained the lower Rhône and tributary soils (Figure 7A). The PCA results also showed that the PC1 (67.3\%) is closely related to $\mathrm{DC}$ or CBT with the positive loading of all cyclic brGDGTs and the negative loading of the non-cyclic GDGTs (Ia, IIa, and IIIa), whereas the PC2 (12.2\%) predominantly reflects the degree of methylation (MBT') with a negative loading of the tetra-methylated GDGT Ia and a positive loading of the 
A
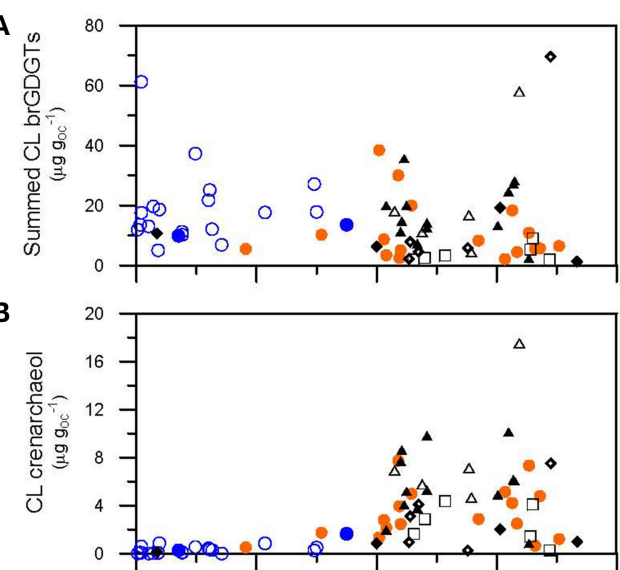

C

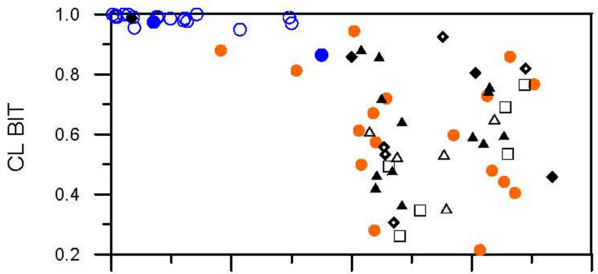

D

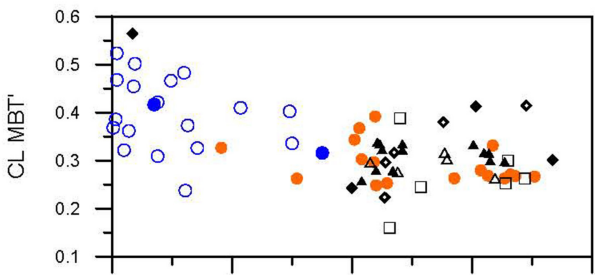

$\mathbf{E}$

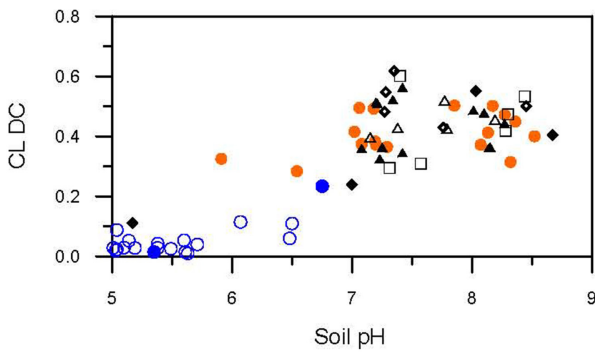

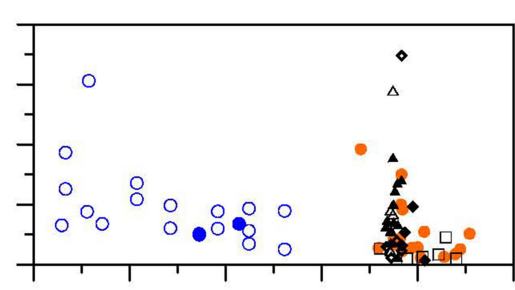
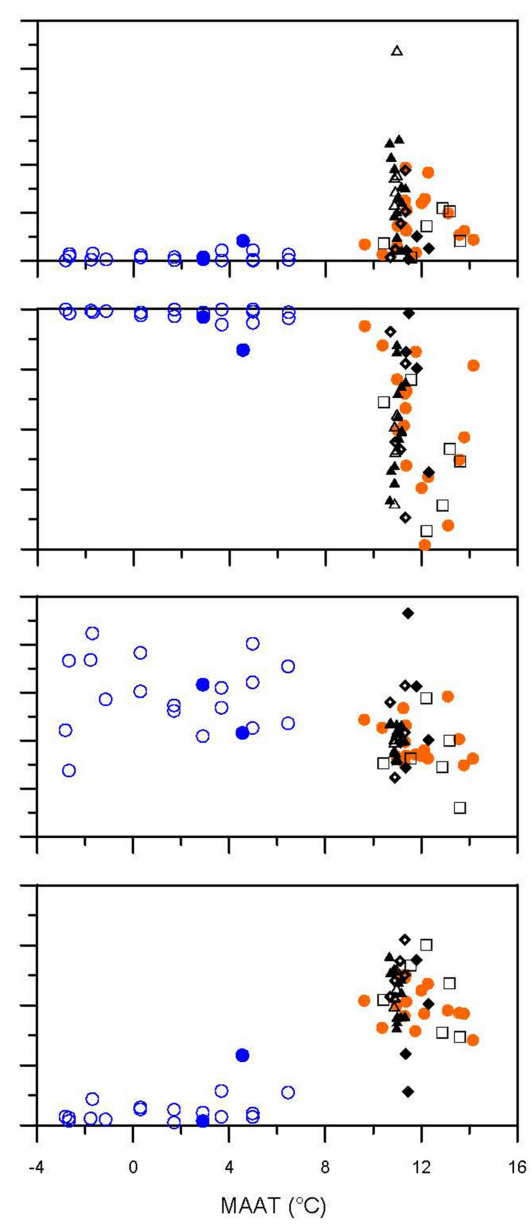

Rhône soils: $\bigcirc$ upstream $\bullet$ downstream Tributary soils: $\Delta$ Saône $\Delta$ Doubs $\square$ Durance $\bullet$ Isère $\diamond$ Ain

FIGURE 8 | Scatter plots of soil pH and MAAT with (A) summed brGDGTs $\left(\mu \mathrm{g} \mathrm{goc}^{-1}\right)$, (B) crenarchaeol $\left(\mu \mathrm{g} \mathrm{goc}{ }^{-1}\right),(C)$ the BIT index, (D) the MBT', and (E) the DC of the CL fractions from soils. Note that the data of the Fiesch soil transect in the upper Rhône River basin are indicated as open blue circles, while others as filled blue circles. hexa-methylated brGDGT IIIa (Figure 7A). Since the degree of cyclization of brGDGTs in soil is primarily determined by soil $\mathrm{pH}$ and the degree of methylation by soil $\mathrm{pH}$ and MAAT (Weijers et al., 2007a; Peterse et al., 2012), the PCA reveals that soil pH explains most of the variances in the brGDGT distribution rather than MAAT in our soil dataset. Indeed CL MBT' is not related to soil $\mathrm{pH}$ or MAAT (Figure 8D), whereas CL DC depends on soil $\mathrm{pH}$ and MAAT (Figure 8E). The relationship between CL DC and MAAT might be due to the correlation between soil $\mathrm{pH}$ and MAAT in the Rhône River system $\left(R^{2}=0.62\right)$. In a global soil dataset, the CL MBT' values were positively correlated with MAAT (Peterse et al., 2012). In our soil dataset, the CL MBT' was highly variable and did not show a strong relationship with MAAT (Figure 8D). In the Fiesch soil transect in the upper Rhône River basin (1188-2848 $\mathrm{m}$ altitude, -2.8 to $6.5^{\circ} \mathrm{C}$ MAAT, and $1203-2085 \mathrm{~mm} \mathrm{MAP}$ ), we also did not observe a positive relationship between the CL MBT' and MAAT (Figure 8D). Hence, it is not surprising that the Fiesch transect dataset also showed no altitudinal trend of the reconstructed MAAT (data not shown) in contrast to other similar studies (e.g., Sinninghe Damsté et al., 2008; Peterse et al., 2009b; Ernst et al., 2013; Coffinet et al., 2014). We do not understand why 


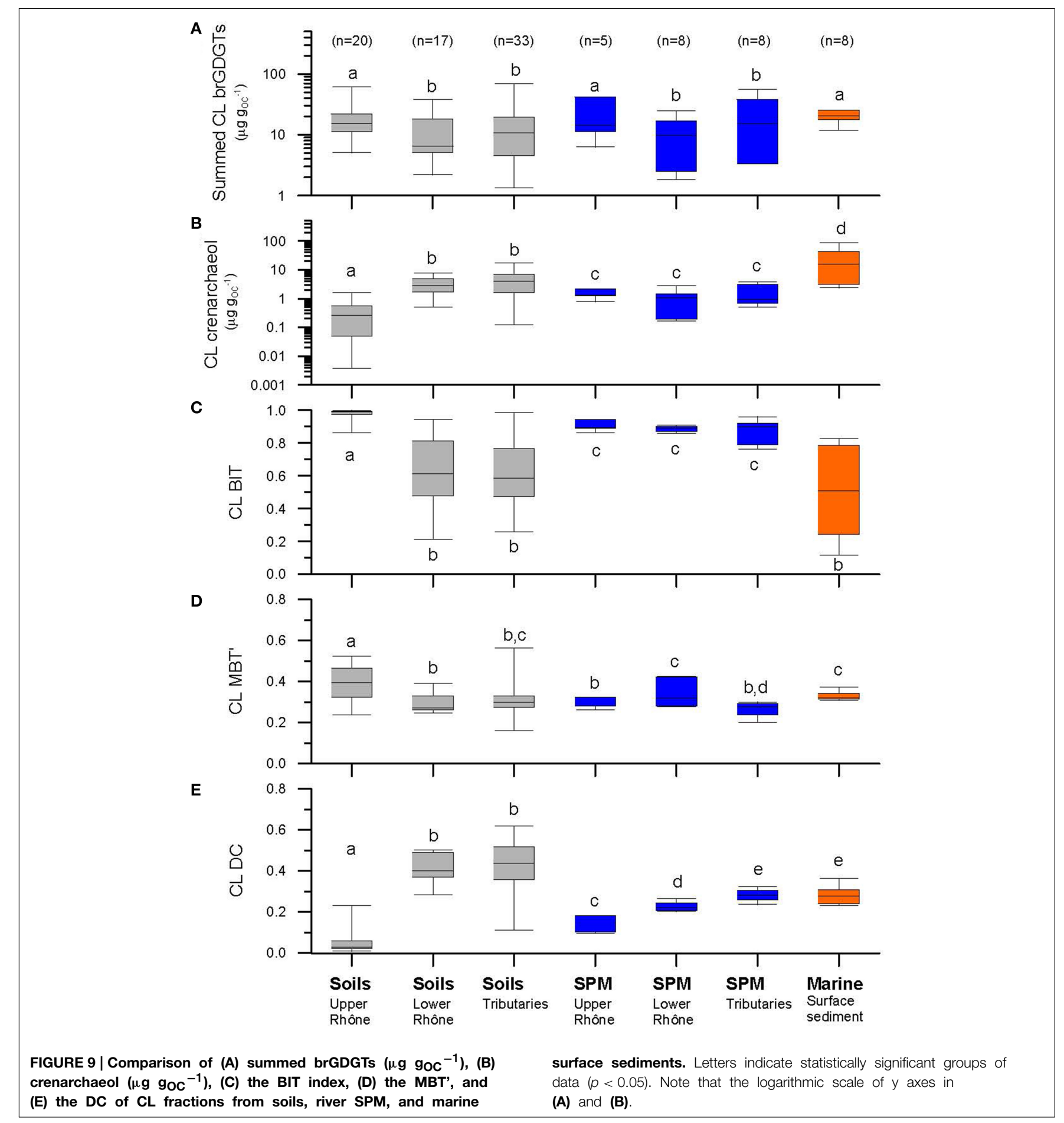

the Fiesch transect data are different to other altitudinal transect data for the moment. Therefore, further studies are required to better constrain potential environmental factors such as nutrient condition in soil influencing the distribution of brGDGTs in soils.

\section{Sources of GDGTs in Rivers}

In this section, we compare CL brGDGT distributions in soils with those in the river SPM to test if soil could be a major source for riverine brGDGTs. However, the results from the river SPM should be considered only as a "snapshot" at the moment of sampling (see Table 1) and should thus be interpreted cautiously. The concentrations of CL brGDGTs in the upper Rhône SPM were comparable to those of the upper Rhône soils and the IPL percentage of brGDGTs $(9 \pm 8)$ was relatively small (Figures 3A, 9A). The distributions of the CL brGDGTs in the SPM and soil were similar (cf. Figures 4A,B). The statistical 


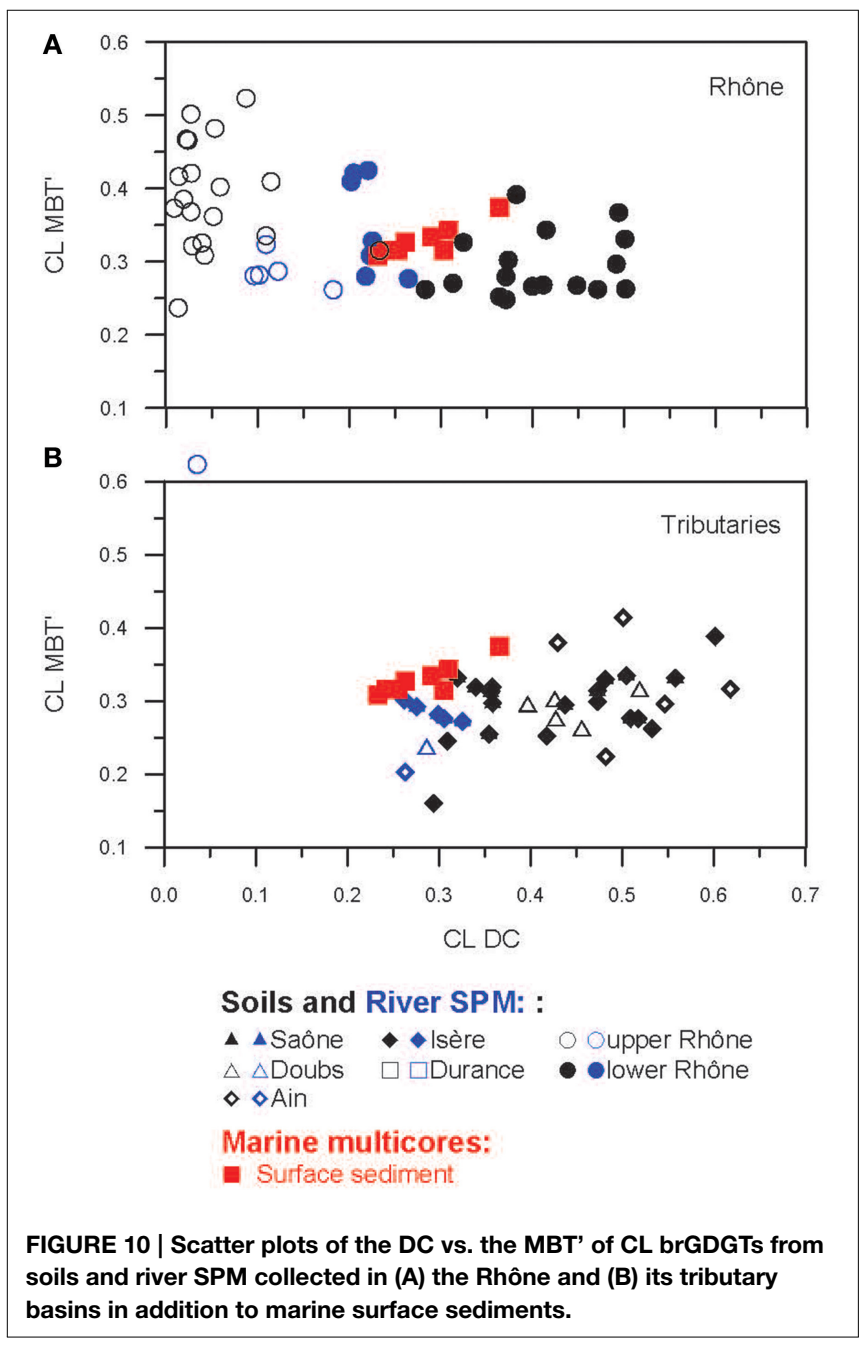

analyses showed that the upper Rhône SPM grouped together with the upper Rhône soils in Cluster 1 (Figure 7). Together, this suggests that the brGDGTs in the SPM of the upper Rhône were predominantly derived from soil erosion, at least at the time of sampling. As noted, this was a time of heavy rainfall, which would have facilitated the transport of soil-derived brGDGTs to the river. In contrast, significantly higher concentrations of CL crenarchaeol were found in the upper Rhône SPM compared to the soils (Figure 9B) and the IPL percentage of crenarchaeol $(48 \pm 4)$ was also substantially higher than that of brGDGTs (Figure 4A). This would point to a substantial in situ production of crenarchaeol in the river as reported for other river systems (Kim et al., 2012; Zell et al., 2013a). As a consequence, CL BIT values were significantly lower in the upper Rhône SPM (albeit still high; i.e., ca. 0.9) than in the upper Rhône soils (Figures 5A, 9C). This is in good agreement with previous studies that showed higher crenarchaeol concentrations and thus lower BIT values in river SPM than in soils (e.g., Kim et al., 2012; Zell et al., 2013a).

The concentrations of CL brGDGTs in the lower Rhône SPM were significantly lower than those of the upper Rhone soils and SPM (Figure 9A). The IPL percentage of brGDGTs $(8 \pm 6)$ in the lower Rhône SPM was, however, comparable to those of the upper Rhône SPM (Figures 4A,B). Notably, the distributions of the CL brGDGTs in the lower Rhône SPM were different in comparison to those of the upper Rhône SPM and soils (cf. Figures 3A,B, 7). Although the limited number of SPM sampling in each tributary hampers a detailed comparison to each other and the lower Rhône SPM, it seems that the tributary SPM had in general CL brGDGT concentrations comparable to those of the lower Rhône SPM (Figures 3, 9A). Their distributions were also basically comparable (cf. Figures 4A,B). Together these data suggest that the brGDGTs in the lower Rhône SPM were not predominantly derived from the upper Rhône basin. This is also evident at the closest station in the lower Rhône tributary downstream of Lake Geneva, which has a brGDGT concentration and distribution that is comparable to that measured at other station along the lower Rhône (Figure 6). This is perhaps not surprising, as it has been shown that Lake Geneva traps most of the SPM transported from the upper Rhône River basin (Loizeau et al., 1997). Accordingly, these results indicate that the CL brGDGTs brought by the river to the sea are restricted to certain areas of the lower Rhône River and its tributary basins, unlike the initial idea that the riverine SPM reflects an integrated brGDGT signal of the whole drainage basin of the river system (Weijers et al., 2007b).

Since brGDGTs in the upper Rhône River do not contribute to brGDGTs of the lower Rhône or only to a small extent, there must be other sources for brGDGTs in the lower Rhône River basin. Soils from the lower Rhône River and its tributary basins could be an important source for the brGDGTs found in the lower Rhône SPM. Generally, this is supported by the similar distributions of brGDGTs in the SPM of the lower Rhône and these soils (Figure 3). Interestingly, only part of the lower Rhône and tributary soils were included in Cluster 2 together with the lower Rhône and tributary SPM (Figure 7). The other lower Rhône and tributary soils were separately grouped as Cluster 3, although this cluster was more closely linked to Cluster 2 than 1 . An alternative source for the brGDGTs in the lower Rhône SPM would be in situ production. Significantly higher CL brGDGT concentrations in river SPM than in soils have been observed in the Amazon River (Zell et al., 2013a) and in the Tagus River (Zell et al., 2014a). This has been interpreted as evidence for in situ production of brGDGTs in rivers. The presence of labile, intact phospholipids in the Amazon River SPM also indicated the occurrence of in situ production of brGDGTs in river waters since IPLs degrade rapidly and must thus be produced by microbes in the river (Zell et al., 2013a). However, in contrast to other river systems, the concentrations of CL brGDGTs in the lower Rhône SPM were comparable to those of the lower Rhône and tributary soils, like in the upper Rhône basin (Figure 9A). Moreover, the IPL percentage of brGDGTs was slightly lower in the lower Rhône SPM (8 \pm 6$)$ than in the Amazon River (11 \pm 7 , Zell et al., 2013a), the Tagus River (12 \pm 8 , Zell et al., 2014a), and the Yenisei River (10 \pm 4 , De Jonge et al., 2014). Hence, the proportion of in situ produced brGDGTs to the riverine brGDGTs is possibly smaller in the Rhône River system than in other river systems. Further information on the potential in situ production of brGDGTs in rivers can be found in the distribution of brGDGTs with the help 
of the MBT' and the DC (cf. Zell et al., 2013a, 2014a). Therefore, we compared the CL MBT' and the CL DC of the river SPM with those of the soils (Figures 9, 10). The CL MBT' differences between the river SPM and the lower Rhône and tributary soils are small (Figure 9D) but the difference in CL DC is clearly significant (Figure 9E). This difference is likely caused by in situ production in the river. Indeed, the distribution of IPL brGDGTs (which reflects the distribution of in situ produced brGDGTs to a larger extent) in the lower Rhône SPM is in agreement with this interpretation (Figure 3).

The concentration of CL crenarchaeol in the lower Rhône and tributary SPM was significantly lower than in the lower Rhône and tributary soils (Figure 9B), while brGDGT concentrations were similar between the SPM and soils. The CL BIT index was significantly higher in the lower Rhône and tributary SPM than in soils from the lower Rhône River and its tributary basins (Figure 9C). This is a quite different situation compared to the upper Rhône River as well as some other rivers, since crenarchaeol is usually produced in higher amounts in the aquatic environments, causing decreased BIT values (e.g., Kim et al., 2012; Zell et al., 2013a). This might be associated with the alkaline soil conditions in the lower Rhône River and its tributary basins as discussed before. Accordingly, the significant difference in the crenarchaeol concentration and the BIT index between the soils and the river SPM in the lower Rhône River and its tributary basins suggests that the crenarchaeol in the river SPM has a mixed origin derived from soils and the in situ production in rivers.

\section{Sources of GDGTs in Marine Surface Sediments}

The concentrations of CL brGDGTs and CL crenarchaeol as well as the distribution of CL GDGTs (i.e., CL BIT, CL MBT', and CL DC) detected in the surface sediment obtained at the marine station A (Figure 2B; see also Table 1), which is located closest to the Grand Rhône River mouth, were comparable to those of the average values of the lower Rhône SPM (Figure 6). The marine surface sediments collected in the Rhône prodelta had an average CL brGDGT concentration of $20 \pm 4 \mu \mathrm{g} \mathrm{gOC}^{-1}$, identical to the value reported previously (19 $\pm 9 \mu \mathrm{g} \mathrm{gOC}^{-1}$, Kim et al., 2010). The results of the PCA and its HCPC showed that the marine surface sediments mostly clustered with the lower Rhône River SPM (Figure 7A). This also suggests that CL brGDGTs in these marine surface sediments predominantly reflect the riverine signals. To further investigate potential sources of brGDGTs in marine surface sediments, we compared the CL MBT' and the CL DC of the lower Rhône SPM with those of marine surface sediments (Figures 9, 10). The CL MBT' values in the marine surface sediments were comparable to those of the lower Rhône SPM (Figure 9D) and showed no offshore trend (Figure 6D). However, the CL DC values in the marine surface sediments were slightly higher than those of the lower Rhône SPM (Figure 9E), showing a similar trend with increasing distance offshore as for the concentrations of CL brGDGTs. Similar studies carried out in other river systems also revealed an increase in the CL DC from soils to the marine environment for a Svalbard fjord (Peterse et al., 2009a), the lower Yangtze River-East China Sea shelf (Zhu et al., 2011), the Pearl River estuary (Zhang et al., 2012), the Portuguese margin (Zell et al., 2014a), and the Amazon shelf (Zell et al., 2014b). This increase in the DC was assumed to be due to in situ production of brGDGTs in the marine environment, since the $\mathrm{pH}$ of the marine environment $(\mathrm{pH} \approx 8)$ is usually higher compared to that of soils and river water. However, in our study area, the soil and river water $\mathrm{pH}$ in the lower Rhône River and its tributary basins was on average 7.7 and thus similar to that of the marine environment. Accordingly, the observed changes in the distribution of CL brGDGTs in the marine surface sediments suggest that the input of riverine brGDGTs is the primary source of brGDGTs in the Rhône prodelta, but the brGDGT composition may be slightly modified by in situ production of brGDGTs in this system.

The average CL crenarchaeol concentration in marine surface sediments was more than twentyfold higher than that of the lower Rhône SPM (Figure 9B). The CL crenarchaeol concentrations markedly increased seawards (Figure 6B). This indicates that the crenarchaeol was mostly produced in the marine system. A decrease in CL BIT values was also observed from the river mouth toward the sea (Figure 6C), while the slightly increasing trend of the CL brGDGT concentration stabilized at $\sim 4 \mathrm{~km}$ away from the Grand Rhône river mouth (Figure 6A). Declining BIT values are, therefore, predominantly determined by the increasing crenarchaeol concentrations in the marine environment.

\section{Conclusion}

Our study conducted in the Rhône River system (NW Mediterranean) shows that the differences in soil $\mathrm{pH}$ are more important than those in MAAT in explaining the variance in the brGDGT distribution in soils. The observed changes in the distribution of brGDGTs in the river SPM suggest that the provenance of brGDGTs brought by the river to the sea might be more restricted to certain areas in the lower Rhône River and its tributary basins. The riverine brGDGTs were further influenced by the in situ production in rivers. In the marine surface sediments, it appears that the input of riverine brGDGTs is the primary source of brGDGTs in the Rhône prodelta, but the brGDGT composition may be slightly modified by the in situ production in the marine environment. It is thus possible to use brGDGTs to reconstruct the terrestrial paleoenvironmental changes from marine sediment cores in this river system. This should be further tested applying the MBT'CBT proxy to sediment cores taken in the Rhône prodelta close to the river mouth based on the improved analytical separation of brGDGTs.

\section{Acknowledgments}

We thank to M. Baas for assistance during Rhône River sampling and to J. Ossebaar and E. C. Hopmans for their analytical support at NIOZ. We also thank to the crew of the R/V Le Suroît and the science party of the "CHACCRA Bent 2" and "RHOSOS" cruises for retrieving the cores. The research leading to these results has received funding from the European Research Council under the European Union's Seventh Framework Programme (FP7/20072013)/ERC grant agreement $n^{\circ}$ [226600]. The work was also supported by the CHACCRA (Climate and Human induced 
Alterations in Carbon Cycling at the River-seA connection, contract $\mathrm{n}^{\circ}$ ANR-06-VULN-001) and EXTREMA (Impact of extreme events on the transfer of anthropogenic pollutants in the coastal zone continuum of the Gulf of Lion-NW Mediterranean Sea, contract $\mathrm{n}^{\circ}$ ANR-06-VULN-005) projects funded by the French National Research Agency.

\section{References}

Bendle, J. A., Weijers, J. W. H., Maslin, M. A., Sinninghe Damsté, J. S., Schouten, S., Hopmans, E. C., et al. (2010). Major changes in glacial and Holocene terrestrial temperatures and sources of organic carbon recorded in the Amazon fan by tetraether lipids. Geochem. Geophys. Geosyst. 11. doi: 10.1029/2010gc003308

Blaga, C. I., Reichart, G. J., Heiri, O., and Sinninghe Damsté, J. S. (2009). Tetraether membrane lipid distributions in lake particulate matter and sediments: a study of 47 European lakes along a North-South transect. J. Paleolimnol. 41, 523-540. doi: $10.1007 / \mathrm{s} 10933-008-9242-2$

Brochier-Armanet, C., Boussau, B., Gribaldo, S., and Forterre, P. (2008). Mesophilic crenarchaeota: proposal for a third archaeal phylum, the Thaumarchaeota. Nat. Rev. Microbiol. 6, 245-252. doi: 10.1038/nrmicro1852

Buckles, L. K., Weijers, J. W. H., Verschuren, D., and Sinninghe Damste, J. S. (2014). Sources of core and intact branched tetraether membrane lipids in the lacustrine environment: anatomy of Lake Challa and its catchment, equatorial East Africa. Geochim. Cosmochim. Acta 140, 106-126. doi: 10.1016/j.gca.2014.04.042

Charmasson, S., Bouisset, P., Radakovitch, O., Pruchon, A. S., and Arnaud, M. (1998). Long-core profiles of Cs-137, Cs-134, Co-60 and Pb-210 in sediment near the Rhône River (Nortwestern Mediterranean Sea). Estuaries 21, 367-378. doi: $10.2307 / 1352836$

Cleveland, C. C., Wieder, W. R., Reed, S. C., and Townsend, A. R. (2010). Experimental drought in a tropical rain forest increases soil carbon dioxide losses to the atmosphere. Ecology 91, 2313-2323. doi: 10.1890/09-1582.1

Coffinet, S., Huguet, A., Williamson, D., Fosse, C., and Derenne, S. (2014). Potential of GDGTs as a temperature proxy along an altitudinal transect at Mount Rungwe (Tanzania). Org. Geochem. 68, 82-89. doi: 10.1016/j.orggeochem.2014.01.004

De Jonge, C., Stadnitskaia, A., Hopmans, E. C., Cherkashov, G., Fedotov, A., and Sinninghe Damsté, J. S. (2014). In situ produced branched glycerol dialkyl glycerol tetraethers in suspended particulate matter from the Yenisei River, Eastern Siberia. Geochim. Cosmochim. Acta 125, 476-491. doi: 10.1016/j.gca.2013.10.031

Dirghangi, S. S., Pagani, M., Hren, M. T., and Tipple, B. J. (2013). Distribution of glycerol dialkyl glycerol tetraethers in soils from two environmental transects in the USA. Org. Geochem. 59, 49-60. doi: 10.1016/j.orggeochem.2013.03.009

Durrieu de Madron, X., Abassi, A., Heussner, S., Monaco, A., Aloisi, J. C., Radakovitch, O., et al. (2000). Particulate matter and organic carbon budgets for the Gulf of Lions (NW Mediterranean). Oceanol. Acta 23, 717-730. doi: 10.1016/S0399-1784(00)00119-5

Ernst, N., Peterse, F., Breitenbach, S. F. M., Syiemlieh, H. J., and Eglinton, T. I. (2013). Biomarkers record environmental changes along an altitudinal transect in the wettest place on Earth. Org. Geochem. 60, 93-99. doi: 10.1016/j.orggeochem.2013.05.004

Eyrolle, F., Radakovitch, O., Raimbault, P., Charmasson, S., Antonelli, C., Ferrand, E., et al. (2012). Consequences of hydrological events on the delivery of suspended sediment and associated radionuclides from the Rhone River to the Mediterranean Sea. J. Soils Sediments 12, 1479-1495. doi: 10.1007/s11368-0120575-0

Fette, M., Weber, C., Peter, A., and Wehrli, B. (2007). Hydropower production and river rehabilitation: a case study on an alpine river. Environ. Model. Assess 12, 257-267. doi: 10.1007/s10666-006-9061-7

Fietz, S., Martínez-Garcia, A., Huguet, C., Rueda, G., and Rosell-Melé, A. (2011). Constraints in the application of the branched and isoprenoid tetraether index as a terrestrial input proxy. J. Geophys. Res. 116. doi: 10.1029/2011jc007062

Harvey, H. R., Fallon, R. D., and Patton, J. S. (1986). The effect of organicmatter and oxygen on the degradation of bacterial-membrane lipids in marine-sediments. Geochim. Cosmochim. Acta 50, 795-804. doi: 10.1016/00167037(86)90355-8
Herfort, L., Schouten, S., Boon, J. P., Woltering, M., Baas, M., Weijers, J. W. H., et al. (2006). Characterization of transport and deposition of terrestrial organic matter in the southern North Sea using the BIT index. Limnol. Oceanogr. 51, 2196-2205. doi: 10.4319/lo.2006.51.5.2196

Hijmans, R. J., Cameron, S. E., Parra, J. L., Jones, P. G., and Jarvis, A. (2005). Very high resolution interpolated climate surfaces for global land areas. Int. J. Climatol. 25, 1965-1978. doi: 10.1002/joc.1276

Hopmans, E. C., Weijers, J. W. H., Schefuá, E., Herfort, L., Sinninghe Damsté, J. S., and Schouten, S. (2004). A novel proxy for terrestrial organic matter in sediments based on branched and isoprenoid tetraether lipids. Earth Planet. Sci. Lett. 224, 107-116. doi: 10.1016/j.epsl.2004.05.012

Huguet, C., Smittenberg, R. H., Boer, W., Sinninghe Damsté, J. S., and Schouten, S. (2007). Twentieth century proxy records of temperature and soil organic matter input in the Drammensfjord, southern Norway. Org. Geochem. 38, 1838-1849. doi: 10.1016/j.orggeochem.2007.06.015

Kim, J.-H., Buscail, R., Bourrin, F., Palanques, A., Sinninghe Damsté, J. S., Bonnin, J., et al. (2009). Transport and depositional process of soil organic matter during wet and dry storms on the Têt inner shelf (NW Mediterranean). Palaeogeogr. Palaeoclimatol. Palaeoecol. 273, 228-238. doi: 10.1016/j.palaeo.2008.04.019

Kim, J.-H., Buscail, R., Fanget, A.-S., Eyrolle-Boyer, F., Bassetti, M.-A., Dorhout, D., et al. (2014). Impact of river channel shifts on tetraether lipids in the Rhône prodelta (NW Mediterranean): implication for the BIT index as an indicator of palaeoflood events. Org. Geochem. 75, 99-108. doi: 10.1016/j.orggeochem.2014.06.011

Kim, J.-H., Ludwig, W., Schouten, S., Kerherve, P., Herfort, L., Bonnin, J., et al. (2007). Impact of flood events on the transport of terrestrial organic matter to the ocean: a study of the Têt River (SW France) using the BIT index. Org. Geochem. 38, 1593-1606. doi: 10.1016/j.orggeochem.2007.06.010

Kim, J.-H., Schouten, S., Buscail, R., Ludwig, W., Bonnin, J., Sinninghe Damsté, J. S., et al. (2006). Origin and distribution of terrestrial organic matter in the NW Mediterranean (Gulf of Lions): exploring the newly developed BIT index. Geochem. Geophys. Geosyst. 7, 1-20. doi: 10.1029/2006gc001306

Kim, J.-H., Zarzycka, B., Buscail, R., Peters, F., Bonnin, J., Ludwig, W., et al. (2010). Contribution of river-borne soil organic carbon to the Gulf of Lions (NW Mediterranean). Limnol. Oceanogr. 55, 507-518. doi: 10.4319/lo.2009.55. 2.0507

Kim, J.-H., Zell, C., Moreira-Turcq, P., Pérez, M. A. P., Abril, G., Mortillaro, J.M., et al. (2012). Tracing soil organic carbon in the lower Amazon River and its tributaries using GDGT distributions and bulk organic matter properties. Geochim. Cosmochim. Acta 90, 163-180. doi: 10.1016/j.gca.2012.05.014

Leininger, S., Urich, T., Schloter, M., Schwark, L., Qi, J., Nicol, G. W., et al. (2006). Archaea predominate among ammonia-oxidizing prokaryotes in soils. Nature 442, 806-809. doi: 10.1038/nature04983

Lengger, S. K., Hopmans, E. C., Sinninghe Damsté, J. S., and Schouten, S. (2012). Comparison of extraction and work up techniques for analysis of core and intact polar tetraether lipids from sedimentary environments. Org. Geochem. 47, 34-40. doi: 10.1016/j.orggeochem.2012.02.009

Loizeau, J.-L., Dominik, J., Luzzi, T., and Vernet, J.-P. (1997). Sediment core correlation and mapping of sediment Accumulation Rates in Lake Geneva (Switzerland, France) using volume magnetic susceptibility. J. Great Lakes Res. 23, 391-402. doi: 10.1016/S0380-1330(97)70921-3

Loomis, S. E., Russell, J. M., Eggermont, H., Verschuren, D., and Sinninghe Damsté, J. S. (2014). Effects of temperature, $\mathrm{pH}$ and nutrient concentration on branched GDGT distributions in East African lakes: implications for paleoenvironmental reconstruction. Org. Geochem. 66, 25-37. doi: 10.1016/j.orggeochem.2013.10.012

Lorrain, A., Savoye, N., Chauvaud, L., Paulet, Y.-M., and Naulet, N. (2003). Decarbonation and preservation method for the analysis of organic $\mathrm{C}$ and $\mathrm{N}$ contents and stable isotope ratios of low-carbonated suspended particulate material. Anal. Chim. Acta 491, 125-133. doi: 10.1016/S0003-2670(03)00815-8 
Ludwig, W., Meybeck, M., and Abousamra, F. (2003). Riverine Transport of Water, Sediments, and Pollutants to the Mediterranean Sea. Athens: UNEP MAP Technical report Series 141, 111.

Maillet, G. M., Vella, C., Berné, S., Friend, P. L., Amos, C. L., Fleury, T. J., et al. (2006). Morphological changes and sedimentary processes induced by the December 2003 flood event at the present mouth of the Grand Rhône River (southern France). Mar. Geol. 234, 159-177. doi: 10.1016/j.margeo.2006.09.025

Ménot, G., Bard, E., Rostek, F., Weijers, J. W. H., Hopmans, E. C., Schouten, S., et al. (2006). Early reactivation of European rivers during the last deglaciation. Science 313, 1623-1625. doi: 10.1126/science.1130511

Miralles, J., Radakovitch, O., and Aloïsi, J. C. (2005). ${ }^{210} \mathrm{~Pb}$ sedimentation rates from the Northwestern Mediterranean margin. Mar. Geol. 216, 155-167. doi: 10.1016/j.margeo.2005.02.020

Olivier, J.-M., Carre, G., Lamouroux, N., Dole-Olivier, M.-J., Malard, F., Bravard, J.-P., et al. (2009). "Chapter 7 - the Rhône River basin," in River of Europe, eds K. Tockner, U. Uehlinger, C. T. Robinson (Amsterdam: Academic Press), 247-295. doi: 10.1016/B978-0-12-369449-2.00007-2

Oppermann, B. I., Michaelis, W., Blumenberg, M., Frerichs, J., Schulz, H. M., Schippers, A., et al. (2010). Soil microbial community changes as a result of long-term exposure to a natural $\mathrm{CO}_{2}$ vent. Geochim. Cosmochim. Acta 74, 2697-2712. doi: 10.1016/j.gca.2010.02.006

Pancost, R. D., and Sinninghe Damsté, J. S. (2003). Carbon isotopic compositions of prokaryotic lipids as tracers of carbon cycling in diverse settings. Chem. Geol. 195, 29-58. doi: 10.1016/S0009-2541(02)00387-X

Pearson, E. J., Juggins, S., Talbot, H. M., Weckstrom, J., Rosen, P., Ryves, D. B., et al. (2011). A lacustrine GDGT-temperature calibration from the Scandinavian Arctic to Antarctic: renewed potential for the application of GDGT paleothermometry in lakes. Geochim. Cosmochim. Acta 75, 6225-6238. doi: $10.1016 /$ j.gca.2011.07.042

Peterse, F., Kim, J.-H., Schouten, S., Kristensen, D. K., Koç, N., and Sinninghe Damsté, J. S. (2009a). Constraints on the application of the MBT/CBT palaeothermometer at high latitude environments (Svalbard, Norway). Org. Geochem. 40, 692-699. doi: 10.1016/j.orggeochem.2009.03.004

Peterse, F., Nicol, G. W., Schouten, S., and Sinninghe Damsté, J. S. (2010). Influence of soil $\mathrm{pH}$ on the abundance and distribution of core and intact polar lipid-derived branched GDGTs in soil. Org. Geochem. 41, 1171-1175. doi: 10.1016/j.orggeochem.2010.07.004

Peterse, F., van der Meer, J., Schouten, S., Weijers, J. W. H., Fierer, N., Jackson, R. B., et al. (2012). Revised calibration of the MBT-CBT paleotemperature proxy based on branched tetraether membrane lipids in surface soils. Geochim. Cosmochim. Acta 96, 215-229. doi: 10.1016/j.gca.2012.08.011

Peterse, F., van der Meer, M. T. J., Schouten, S., Jia, G., Ossebaar, J., Blokker, J., et al. (2009b). Assessment of soil n-alkane $\delta \mathrm{D}$ and branched tetraether membrane lipid distributions as tools for paleoelevation reconstruction. Biogeosciences 6, 2799-2807. doi: 10.5194/bg-6-2799-2009

Pitcher, A., Hopmans, E. C., Schouten, S., and Sinninghe Damsté, J. S. (2009). Separation of core and intact polar archaeal tetraether lipids using silica columns: insights into living and fossil biomass contributions. Org. Geochem. 40, 12-19. doi: 10.1016/j.orggeochem.2008.09.008

Pont, D., Simonnet, J. P., and Walter, A. V. (2002). Medium-term changes in suspended sediment delivery to the ocean: consequences of catchment heterogeneity and river management (Rhône river, France). Estuar. Coast. Shelf Sci. 54, 1-18. doi: 10.1006/ecss.2001.0829

Powers, L. A., Werne, J. P., Johnson, T. C., Hopmans, E. C., Sinninghe Damsté, J. S., and Schouten, S. (2004). Crenarchaeotal lipids in lake sediments: a new paleotemperature proxy for continental paleoclimate reconstruction? Geology 32, 613-616. doi: 10.1130/G20434.1

Radakovitch, O., Charmasson, S., Arnaud, M., and Bouisset, P. (1999). ${ }^{210} \mathrm{~Pb}$ and caesium accumulation in the Rhone delta sediment. Estuar. Coast. Shelf Sci. 48, 77-92. doi: 10.1006/ecss.1998.0405

Schouten, S., Hopmans, E. C., and Sinninghe Damsté, J. S. (2013). The organic geochemistry of glycerol dialkyl glycerol tetraether lipids: a review. Org. Geochem. 54, 19-61. doi: 10.1016/j.orggeochem.2012.09.006

Schouten, S., Huguet, C., Hopmans, E. C., Kienhuis, M. V. M., and Sinninghe Damsté, J. S. (2007). Analytical methodology for $\mathrm{TEX}_{86}$ paleothermometry by high-performance liquid chromatography/atmospheric pressure chemical ionization-mass spectrometry. Anal. Chem. 79, 2940-2944. doi: $10.1021 / \mathrm{ac} 062339 \mathrm{v}$
Sinninghe Damsté, J. S., Hopmans, E. C., Pancost, R. D., Schouten, S., and Geenevasen, J. A. J. (2000). Newly discovered non-isoprenoid glycerol dialkyl glycerol tetraether lipids in sediments. Chem. Commun. 1683-1684. doi: $10.1039 / \mathrm{b} 004517 \mathrm{i}$

Sinninghe Damsté, J. S., Hopmans, E. C., Schouten, S., van Duin, A. C. T., and Geenevasen, J. A. J. (2002). Crenarchaeol: the characteristic core glycerol dibiphytanyl glycerol tetraether membrane lipid of cosmopolitan pelagic crenarchaeota. J. Lipid Res. 43, 1641-1651. doi: 10.1194/jlr.M200148-JLR200

Sinninghe Damsté, J. S., Ossebaar, J., Abbas, B., Schouten, S., and Verschuren, D. (2009). Fluxes and distribution of tetraether lipids in an equatorial African lake: constraints on the application of the TEX 86 palaeothermometer and BIT index in lacustrine settings. Geochim. Cosmochim. Acta 73, 4232-4249. doi: 10.1016/j.gca.2009.04.022

Sinninghe Damsté, J. S., Ossebaar, J., Schouten, S., and Verschuren, D. (2008). Altitudinal shifts in the branched tetraether lipid distribution in soil from Mt. Kilimanjaro (Tanzania): implications for the MBT/CBT continental palaeothermometer. Org. Geochem. 39, 1072-1076. doi: 10.1016/j.orggeochem.2007.11.011

Sinninghe Damsté, J. S., Rijpstra, W. I., Hopmans, E. C., Foesel, B. U., Wüst, P. K., Overmann, J., et al. (2014). Ether- and ester-bound iso-diabolic acid and other lipids in members of acidobacteria subdivision 4. Appl. Environ. Microbiol. 80, 5207-5218. doi: 10.1128/AEM.01066-14

Sinninghe Damsté, J. S., Rijpstra, W. I. C., Hopmans, E. C., Weijers, J. W. H., Foesel, B. U., Overmann, J., et al. (2011). 13,16-dimethyl octacosanedioic acid (iso-diabolic acid), a common membrane-spanning lipid of Acidobacteria Subdivisions 1 and 3. Appl. Environ. Microbiol. 77, 4147-4154. doi: 10.1128/AEM.00466-11

Smith, R. W., Bianchi, T. S., and Li, X. (2012). A re-evaluation of the use of branched GDGTs as terrestrial biomarkers: implications for the BIT Index. Geochim. Cosmochim. Acta 80, 14-29. doi: 10.1016/j.gca.2011.11.025

Spang, A., Hatzenpichler, R., Brochier-Armanet, C., Rattei, T., Tischler, P., Spieck, E., et al. (2010). Distinct gene set in two different lineages of ammonia-oxidizing archaea supports the phylum Thaumarchaeota. Trends Microbiol. 18, 331-340. doi: 10.1016/j.tim.2010.06.003

Strong, D. J., Flecker, R., Valdes, P. J., Wilkinson, I. P., Rees, J. G., Zong, Y. Q., et al. (2012). Organic matter distribution in the modern sediments of the Pearl River estuary. Org. Geochem. 49, 68-82. doi: 10.1016/j.orggeochem.2012.04.011

Thill, A., Moustier, S., Garnier, J.-M., Estournel, C., Naudin, J.-J., and Bottero, J.-Y. (2001). Evolution of particle size and concentraiton in the Rhône river mixing zone: influence of salt flocculation. Cont. Shelf Res. 21, 2127-2140. doi: 10.1016/S0278-4343(01)00047-4

Tierney, J. E., and Russell, J. M. (2009). Distributions of branched GDGTs in a tropical lake system: implications for lacustrine application of the MBT/CBT paleoproxy. Org. Geochem. 40, 1032-1036. doi: 10.1016/j.orggeochem.2009.04.014

Ulses, C., Estournel, C., Durrieu de Madron, X., and Palanques, A. (2008). Suspended sediment transport in the Gulf of Lions (NW Mediterranean): impact of extreme storms and floods. Cont. Shelf Res. 28, 2048-2070. doi: 10.1016/j.csr.2008.01.015

Verschuren, D., Sinninghe Damsté, J. S., Moernaut, J., Kristen, I., Blaauw, M., Fagot, M., et al. (2009). Half-precessional dynamics of monsoon rainfall near the East African Equator. Nature 462, 637-641. doi: 10.1038/nature 08520

Walsh, E. M., Ingalls, A. E., and Keil, R. G. (2008). Sources and transport of terrestrial organic matter in Vancouver Island fjords and the VancouverWashington Margin: a multiproxy approach using $\delta^{13} \mathrm{C}_{\text {org }}$, lignin phenols, and the ether lipid BIT index. Limnol. Oceanogr. 53, 1054-1063. doi: 10.4319/lo.2008.53.3.1054

Weijers, J. W. H., Bernhardt, B., Peterse, F., Werne, J. P., Dungait, J. A. J., Schouten, S., et al. (2011). Absence of seasonal patterns in MBT-CBT indices in mid-latitude soils. Geochim. Cosmochim. Acta 75, 3179-3190. doi: 10.1016/j.gca.2011.03.015

Weijers, J. W. H., Panoto, E., van Bleijswijk, J., Schouten, S., Rijpstra, W. I. C., Balk, M., et al. (2009a). Constraints on the biological source(s) of the orphan branched tetraether membrane lipids. Geomicrobiol. J. 26, 402-414. doi: 10.1080/01490450902937293

Weijers, J. W. H., Schefuß, E., Kim, J.-H., Sinninghe Damsté, J. S., and Schouten, S. (2014). Constraints on the sources of branched tetraether 
membrane lipids in distal marine sediments. Org. Geochem. 72, 14-22. doi: 10.1016/j.orggeochem.2014.04.011

Weijers, J. W. H., Schefuß, E., Schouten, S., and Sinninghe Damsté, J. S. (2007b). Coupled thermal and hydrological evolution of tropical Africa over the last deglaciation. Science 315, 1701-1704. doi: 10.1126/science.1138131

Weijers, J. W. H., Schouten, S., Hopmans, E. C., Geenevasen, J. A. J., David, O. R. P., Coleman, J. M., et al. (2006a). Membrane lipids of mesophilic anaerobic bacteria thriving in peats have typical archaeal traits. Environ. Microbiol. 8, 648-657. doi: 10.1111/j.1462-2920.2005.00941.x

Weijers, J. W. H., Schouten, S., Schefuá, E., Schneider, R. R., and Sinninghe Damsté, J. S. (2009b). Disentangling marine, soil and plant organic carbon contributions to continental margin sediments: a multi-proxy approach in a 20,000 year sediment record from the Congo deep-sea fan. Geochim. Cosmochim. Acta 73, 119-132. doi: 10.1016/j.gca.2008.10.016

Weijers, J. W. H., Schouten, S., Spaargaren, O. C., and Sinninghe Damsté, J. S. (2006b). Occurrence and distribution of tetraether membrane lipids in soils: implications for the use of the $\mathrm{TEX}_{86}$ proxy and the BIT index. Org. Geochem. 37, 1680-1693. doi: 10.1016/j.orggeochem.2006.07.018

Weijers, J. W. H., Schouten, S., van den Donker, J. C., Hopmans, E. C., and Sinninghe Damsté, J. S. (2007a). Environmental controls on bacterial tetraether membrane lipid distribution in soils. Geochim. Cosmochim. Acta 71, 703-713. doi: 10.1016/j.gca.2006.10.003

Weijers, J. W. H., Wiesenberg, G. L. B., Bol, R., Hopmans, E. C., and Pancost, R. D. (2010). Carbon isotopic composition of branched tetraether membrane lipids in soils suggest a rapid turnover and a heterotrophic life style of their source organism(s). Biogeosciences 7, 2959-2973. doi: 10.5194/bg-7-2959-2010

White, D. C., Davis, W. M., Nickels, J. S., King, J. D., and Bobbie, R. J. (1979). Determination of the sedimentary microbial biomass by extractable lipid phosphate. Oecologia 40, 51-62. doi: 10.1007/BF00388810

Wright, L. D., and Friedrichs, C. T. (2006). Gravity-driven sediment transport on continental shelves: a status report. Cont. Shelf Res. 26, 2092-2107. doi: 10.1016/j.csr.2006.07.008

Xie, S., Pancost, R. D., Chen, L., Evershed, R. P., Yang, H., Zhang, K., et al. (2012). Microbial lipid records of highly alkaline deposits and enhanced aridity associated with significant uplift of the Tibetan Plateau in the Late Miocene. Geology 40, 291-294. doi: 10.1130/G32570.1

Yang, G., Zhang, C. L., Xie, S., Chen, Z., Gao, M., Ge, Z., et al. (2013). Microbial glycerol dialkyl glycerol tetraethers from river water and soil near the three gorges dam on the Yangtze River. Org. Geochem. 56, 40-50. doi: 10.1016/j.orggeochem.2012.11.014

Yang, H., Ding, W., Wang, J., Jin, C., He, G., Qin, Y., et al. (2011). Soil $\mathrm{pH}$ impact on microbial tetraether lipids and terrestrial input index (BIT) in China. Sci. China Earth Sci. 55, 236-245. doi: 10.1007/s11430-0114295-x

Yang, H., Pancost, R. D., Dang, X., Zhou, X., Evershed, R. P., Xiao, G., et al. (2014). Correlations between microbial tetraether lipids and environmental variables in Chinese soils: optimizing the paleo-reconstructions in semi-arid and arid regions. Geochim. Cosmochim. Ac. 126, 49-69. doi: 10.1016/j.gca.2013.10.041

Zell, C., Kim, J.-H., Abril, G., Sobrinho, R. L., Dorhout, D., Moreira-Turcq, P., et al. (2013b). Impact of seasonal hydrological variation on the distributions of tetraether lipids along the Amazon River in the central Amazon basin: implications for the MBT/CBT paleothermometer and the BIT index. Front. Microbiol. 4:228. doi: 10.3389/fmicb.2013.00228

Zell, C., Kim, J.-H., Balsinha, M., Dorhout, D., Fernandes, C., Baas, M., et al. (2014a). Transport of branched tetraether lipids from the Tagus River basin to the coastal ocean of the Portuguese margin: consequences for the interpretation of the MBT'/CBT paleothermometer. Biogeosciences 11, 5637-5655. doi: 10.5194/bg-11-5637-2014

Zell, C., Kim, J.-H., Hollander, D., Lorenzoni, L., Baker, P., Silva, C., et al. (2014b). Source and distribution of branched and isoprenoid tetraether lipids on the Amazon shelf and deep-sea fan: implications for the use of GDGTbased paleothermeters in marine sediments. Geochim. Cosmochim. Acta 139, 293-312. doi: 10.1016/j.gca.2014.04.038

Zell, C., Kim, J.-H., Moreira-Turcq, P., Abril, G., Hopmans, E. C., Bonnet, M.P., et al. (2013a). Disentangling the origins of branched tetraether lipids and crenarchaeol in the lower Amazon River: implications for GDGT-based proxies. Limnol. Oceanogr. 58, 343-353. doi: 10.4319/lo.2013.58.1.0343

Zhang, C. L., Wang, J., Wei, Y., Zhu, C., Huang, L., and Dong, H. (2012). Production of branched tetraether lipids in the lower pearl river and estuary: effects of extraction methods and impact on bGDGT proxies. Front. Microbiol. 2:274. doi: 10.3389/fmicb.2011.00274

Zhu, C., Weijers, J. W. H., Wagner, T., Pan, J. M., Chen, J. F., and Pancost, R. D. (2011). Sources and distributions of tetraether lipids in surface sediments across a large river-dominated continental margin. Org. Geochem. 42, 376-386. doi: 10.1016/j.orggeochem.2011.02.002

Zuo, Z., Eisma, D., Gieles, R., and Beks, J. (1997). Accumulation rates and sediment deposition in the northwestern Mediterranean. Deep-Sea Res. Part I-Top. Stud. Oceanogr. 44, 597-609. doi: 10.1016/S0967-0645(96)00083-5

Conflict of Interest Statement: The Associate Editor Dr. Moritz Lehmann declares that, despite having collaborated with author, Dr. Jaap S. Sinninghe Damsté, the review process was handled objectively. The authors declare that the research was conducted in the absence of any commercial or financial relationships that could be construed as a potential conflict of interest.

Copyright (c) 2015 Kim, Ludwig, Buscail, Dorhout and Sinninghe Damsté. This is an open-access article distributed under the terms of the Creative Commons Attribution License (CC BY). The use, distribution or reproduction in other forums is permitted, provided the original author(s) or licensor are credited and that the original publication in this journal is cited, in accordance with accepted academic practice. No use, distribution or reproduction is permitted which does not comply with these terms. 